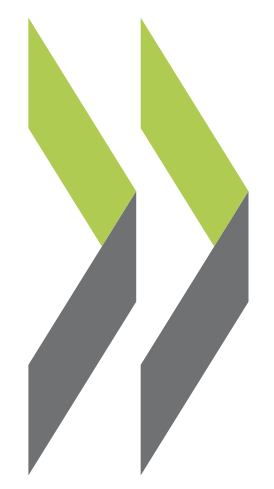

OECD Corporate Governance Working Papers No. 18

\title{
Stocktaking of Anti- Corruption and Business Integrity Measures for Southern African SOEs
}

\section{Mary Crane-Charef}




\section{OECD CORPORATE GOVERNANCE WORKING PAPERS}

OECD Corporate Governance Working Papers provide timely analysis and information on national and international corporate governance issues and developments, including state ownership and privatisation policies. The working paper series is designed to make select studies by the OECD Corporate Governance Committee, OECD staff members and outside consultants available to a broad audience.

The papers are generally available only in their original language, English or French, with a summary in the other if available.

OECD Working Papers should not be reported as representing the official views of the OECD or of its member countries. The opinions expressed and arguments employed are those of the authors.

Working Papers describe preliminary results or research in progress by the author(s) and are published to stimulate discussion on a broad range of issues on which the OECD works. Comments on Working Papers are welcomed, and may be sent to corporate.affairs@oecd.org or Directorate for Financial and Enterprise Affairs, Corporate Affairs Division, OECD, 2 rue André-Pascal, 75775 Paris Cedex 16, France.

This document and any map included herein are without prejudice to the status of or sovereignty over any territory, to the delimitation of international frontiers and boundaries and to the name of any territory, city or area.

\section{OECD CORPORATE GOVERNANCE WORKING PAPERS}

are published on www.oecd.org/daf/corporateaffairs/wp

(c) OECD 2015

Applications for permission to reproduce or translate all or part of this material should be made to: OECD Publishing, rights@oecd.org or by fax 33145249930. 


\title{
Stocktaking of Anti-Corruption and Business Integrity Measures for Southern African SOEs
}

\author{
By Mary Crane-Charef ${ }^{\star}$
}

\begin{abstract}
This report aims to provide an overview of business integrity and anti-bribery legislation, policies and practices applicable to state-owned enterprises (SOEs) operating across the Southern African Development Community (SADC) region. Part 1 provides a rationale for considering the impact that corruption-prevention and business integrity measures have had in some jurisdictions, based on available academic literature on this subject. Part 2 summarises the framework in seven SADC countries for combating corruption and for encouraging responsible business practices. It also focuses on the application of this framework to SOEs by governments, as well as measures taken by SOEs to limit their exposure to the risks of corruption. The report was undertaken on behalf of the OECD Network on Corporate Governance of State-Owned Enterprises in Southern Africa and is based on voluntary responses to a questionnaire and supplemented with desk research.
\end{abstract}

Approved by Pierre Poret, Deputy Director, OECD Directorate for Financial and Enterprise Affairs

JEL Codes: G3, G30, G38, G39

Keywords: Corruption, anti-corruption, integrity, corporate governance, government policy and regulation

\footnotetext{
* Mary Crane-Charef works at the Corporate Affairs Division of OECD's Directorate for Financial and Enterprise Affairs. This work benefited from inputs by members of the Southern Africa Network on Governance of State-Owned Enterprises and financial support from the Norwegian government.
} 


\section{TABLE OF CONTENTS}

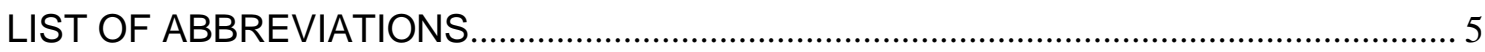

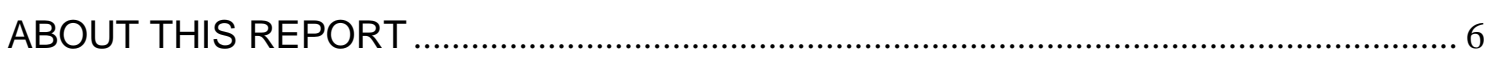

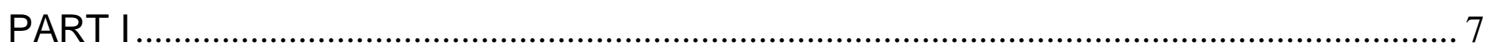

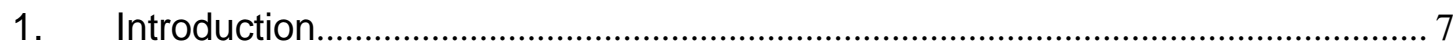

2. Why focus on anti-corruption and business integrity ........................................ 8

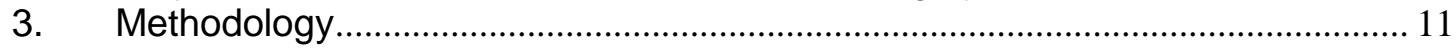

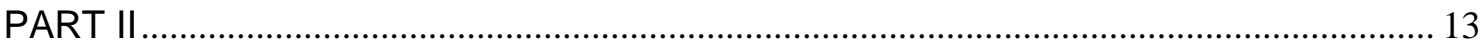

1. Policy, legal, and regulatory measures for combating corruption........................ 13

2. SOE-specific measures for combating corruption and promoting

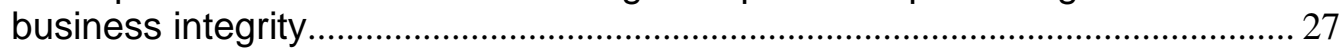

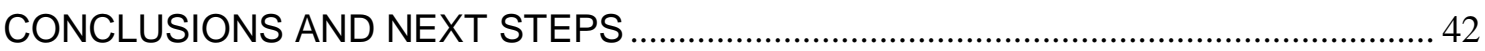

ANNEX 1. QUESTIONNAIRE: STOCKTAKING OF ANTI-CORRUPTION AND BUSINESS INTEGRITY MEASURES FOR SOUTHERN AFRICAN SOES .................. 43

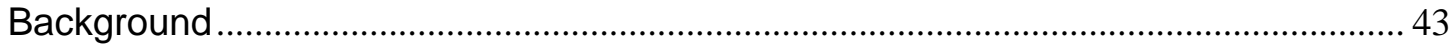

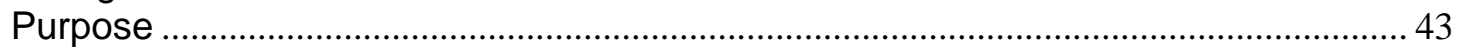

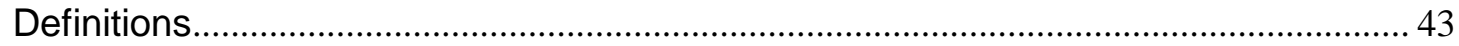

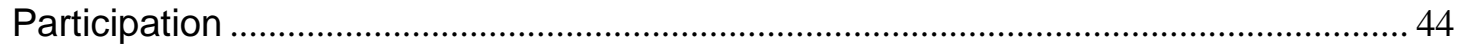

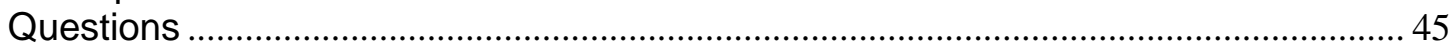

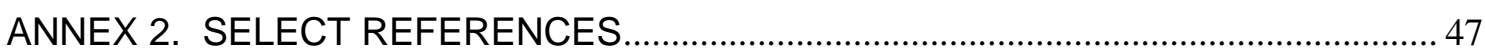

\section{Tables}

Table 1. Economic and governance rankings of SADC countries....................... 10

Table 2. UNCAC corruption offences .......................................................... 12

Table 3. Status of SADC signature and ratification of international and regional anti-corruption instruments.......................................... 14

Table 4. National implementing legislation for specific UNCAC corruption offences in Botswana, DRC, Malawi, Mozambique, Seychelles \& Zimbabwe 15

Table 5. Size and organization of SOE sectors in Botswana, the DRC, Malawi, Mozambique, Seychelles, and Zimbabwe 29

\section{Figures}

Figure 1. Correlation between economic output and perceived corruption levels .... 9

\section{Boxes}

Box 1. Extract from the Guidelines on the Governance of State-Owned Enterprises in

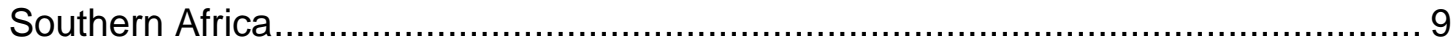
Box 2. Highlights: SOE-led anti-corruption and business integrity initiatives in Southern Africa..... 30 


\section{LIST OF ABBREVIATIONS}

\begin{tabular}{|l|l|}
\hline Art. & Article \\
\hline AU & African Union \\
\hline AUCPCC & AU Convention on Preventing and Combating Corruption \\
\hline COPIREP & $\begin{array}{l}\text { Comité de pilotage de la réforme des entreprises du portefeuille de l'état } \\
\text { ("Steering committee for the reform of the state's portfolio of companies") }\end{array}$ \\
\hline DRC & Democratic Republic of Congo \\
\hline GCCC & $\begin{array}{l}\text { "Gabinete Central de Combate à Corrupçã" (Central Office for Combating } \\
\text { Corruption, Mozambique) }\end{array}$ \\
\hline GDP & Gross domestic product \\
\hline IGEPE & $\begin{array}{l}\text { Instituto de Gestao das Participacoes do Estado ("Institute for the Management of } \\
\text { State Holdings", Mozambique) }\end{array}$ \\
\hline IMF & International Monetary Fund \\
\hline OECD & Organisation for Economic Co-operation and Development \\
\hline PEEPA & Public Enterprise Evaluation and Privatisation Agency (Botswana) \\
\hline PEMC & Public Enterprise Monitoring Commission (Seychelles) \\
\hline SADC & Southern Africa Development Community \\
\hline SOE & State-owned enterprise \\
\hline SPAC & SADC Protocol against Corruption \\
\hline TI & Transparency International \\
\hline UNCAC & United Nations Convention against Corruption \\
\hline UNDP & United Nations Development Programme \\
\hline USD & United States Dollar \\
\hline WEF & World Economic Forum \\
\hline WGI & World Bank Worldwide Governance Indicators \\
\hline ZACC & Zimbabwe Anti-Corruption Commission \\
\hline
\end{tabular}




\section{ABOUT THIS REPORT}

This report is organised as follows: Part 1 provides a rationale for considering the impact that corruption-prevention and business integrity measures have had in some jurisdictions, based on available academic literature on this subject. Part 2 summarises the framework in seven SADC countries for combating corruption and for encouraging responsible business practices. It also focuses on the application of this framework to SOEs by governments, as well as measures taken by SOEs to limit their exposure to the risks of corruption.

This report is based on voluntary responses to a questionnaire circulated by the OECD Secretariat and supplemented with desk research. Special thanks are extended to the agencies from the following governments that contributed to this exercise: Botswana's Public Enterprise Evaluation and Privatisation Agency, the Democratic Republic of Congo's (DRC) Comité de Pilotage de la Réforme des Entreprises du Portefeuille de l'état, Malawi's Department of Statutory Corporations in the Office of the President and Cabinet, Mozambique's Instituto de Gestao das Participacoes do Estado, Seychelles' Public Enterprise Monitoring Commission, South Africa's Department of Public Enterprises (DPE), and the Zimbabwe Anti-Corruption Commission and the Zimbabwean State Enterprise Restructuring Agency.

The report was prepared at the request of the Southern Africa Network on Governance of State-Owned Enterprises ${ }^{1}$-a regional co-operation initiative aimed at improving the corporate governance of SOEs, and mainly covering the member economies of the SADC region, plus Kenya. This report constitutes part of a larger and ongoing Network effort to share experiences and good practices for preventing corruption and promoting ethical and responsible business conduct in SOEs. 


\section{PART I}

\section{Introduction}

Corruption undermines good governance, sustainable economic development, and functioning markets. State-owned enterprises (SOEs) are uniquely exposed to the risk of corruption, due to their proximity to government and de facto elected officials. Many SOEs also operate in industries with a higher corruption-risk incidence: These include the utilities, oil and gas, power generation and transmission, transportation, telecommunications, and banking and finance. ${ }^{2}$ As an illustration of SOEs' heightened exposure to corruption risks, an analysis of all transnational bribery enforcement actions brought by countries Party to the OECD Anti-Bribery Convention between 1999 and 2012 finds that nearly a third of all bribery cases involved the bribery of SOE employees, while $80.11 \%$ of the value of all bribes paid to SOE employees. ${ }^{3}$

SOEs can be both passive and active actors when it comes to corruption. Corruption risks may include the bribery of SOEs employees by other companies and their employees to obtain unfair business advantages. Or, SOEs and their employees may feel pressured to bribe or take advantage of their unique position in the market to win unfair advantages, especially where such practices are perceived to be commonplace among private competitors and in certain industries. SOEs may also be prone to corruption through privatisation or public procurement processes. In some jurisdictions, SOEs are held responsible for the corrupt acts of their employees.

Given their central role as providers of public services and revenue generators, clean and efficient SOEs are important to good governance and a well-functioning economy. This stocktaking report aims to broadly outline the anti-corruption and business integrity measures that may be applicable to SOEs in some southern African countries. It also aims to identify horizontal challenges, as well as examples of good practice in their application. By better understanding SOEs' unique exposure to the risk of bribery and corruption, governments may be better able to ensure they act as "good corporate citizens" and serve as models for other companies operating in their markets.

This paper is divided into two parts. Part 1 provides a rationale for considering the impact that corruption-prevention and business integrity measures have had in some

2. According to Transparency International's 2011 Bribe Payers Index, companies in these business sectors are more likely to involve bribery. These sectors also represent those in which the majority of SOEs from OECD countries operate, according to data compiled by the OECD.

3. OECD (2014), The Foreign Bribery Report: An Analysis of the Crime of Bribery of Foreign Public Officials, OECD Publishing. The Foreign Bribery Report defines a 'public enterprise' as any enterprise, regardless of its legal form, over which a government, or governments, may, directly or indirectly, exercise a dominant influence. This is deemed to be the case, inter alia, when the government or governments hold the majority of the enterprises subscribed capital, control the majority of votes attaching to shares issued by the enterprise or an appoint a majority of the members of the enterprises administrative or managerial body or supervisory board. 
jurisdictions, based on available academic literature on this subject. Part 2 summarises the framework in seven countries for combating corruption and for encouraging clean business practices. ${ }^{4}$ It also focuses on the application of this framework to SOEs by governments, as well as measures taken by SOEs to limit their exposure to the risks of corruption.

\section{Why focus on anti-corruption and business integrity}

Policy-makers of Southern African economies recognise the challenges of corruption, and the negative impact it has, not only in impairing efficient and transparent SOE operations, but also the broader impact it has on governance, the economy, and everyday citizens, who ultimately pay the price for corruption. For example, Malawi's National AntiCorruption Strategy (described further in Part II below) provides a list of "corruption costs", which include:

- Retarding social, political, and economic development;

- Crippling Government's ability to deliver social services as public funds are illegally diverted to private use;

- Undermining democratic values of good governance, political stability, and the rule of law;

- Discouraging foreign and domestic investment;

- Breeding criminal behaviour, and hence endangers public security; and

- Violating the rights of the people who experience corruption.

This is also a timely subject in the Southern Africa region, given the prominent role attributed to the issues of anti-corruption and ethical conduct which are addressed in the in the 2014 Guidelines on the Governance of Sate-Owned Enterprises in Southern Africa ${ }^{5}$, a regional instrument agreed by members of the OECD-Southern Africa Network on the Governance of State-Owned Enterprises. ${ }^{6}$ Corporate ethics goes to the core of promoting effective corporate governance starting from the board of directors and executive management, to the conduct of employees and relations with stakeholders. Chapter IV of the Regional Guidelines (Corporate Ethics and Stakeholder Relations) call on SOE boards to develop, implement, and communicate internal codes of ethics that apply to all employees. Among the Southern African economies, anti-corruption compliance is an increasingly important issue for boards of directors and senior management. The strengthening of anticorruption laws and increased enforcement in some jurisdictions have meant that directors

4. Part B of this paper is not meant to be an exhaustive assessment of the anti-corruption framework in countries participating in the stocktaking exercise. Country responses are complemented in this section by expert anti-corruption assessments made in the context of, for example, evaluations of countries' implementation of international anti-corruption instruments, including the UN Convention against Corruption and the African Union Convention on Preventing and Combating Corruption, described more fully below.

5. See online here: www.oecd.org/daf/ca/SouthernAfricanSOEGuidelines Revised 22.1.14.pdf

6. The Network is a regional cooperation initiative aimed at improving the corporate governance of SOEs, and mainly covering the member economies of SADC plus Kenya: www.oecd.org/daf/ca/soeafrica.htm 
and executives may be held personally liable if they are deemed to have failed to either properly implement or subsequently monitor and oversee the enterprise's internal controls, ethics, and compliance measures. There is also the reputational damage that accompanies such cases, negatively impacting the ability of a company to attract investment and business opportunities.

\section{Box 1. Extract from the Guidelines on the Governance of State-Owned Enterprises in Southern Africa}

The Guidelines on the Governance of State-Owned Enterprises in Southern Africa specifically address the risk corruption poses to state-owned enterprises, and calls on SOE boards to work with stakeholders to combat corruption. The annotations to Chapter IV of the Guidelines state, in particular:

The fight against corruption is of paramount importance. State-owned enterprises, if not properly checked, can act as veritable poles of corruption, acting both as bribe solicitors and themselves engaging in bribery. Commercial SOEs may be under pressure to bribe to stay in business, especially where such practices are common place among private competitors in certain industries. SOE officials can be bribed by private companies to obtain lucrative contracts and other abusive business contracts. SOEs may also be prone to corruption through privatisation processes or in their public procurement practices. Likewise, SOEs can be victims of abuse and fraud by their own employees. Regardless of whether it is passive or active, bribery is deeply harmful to the corporate performance of the SOE. The benefits of a transparent enterprise culture are voided if corruption is tolerated, because corrupt practices are by nature non-transparent. Moreover, proper incentive structures, linked to operating performance, are key to motivating employees and executives. In a corrupt environment the State may find itself rewarding dishonesty rather than merit. The application of international and regional conventions on anti-corruption should also apply to the commercial activities of SOEs, regardless as to whether the SOE is an active or passive party.

Figure 1. Correlation between economic output and perceived corruption levels

Control of corruption indicator and output level

(176 countries, 2011 data)

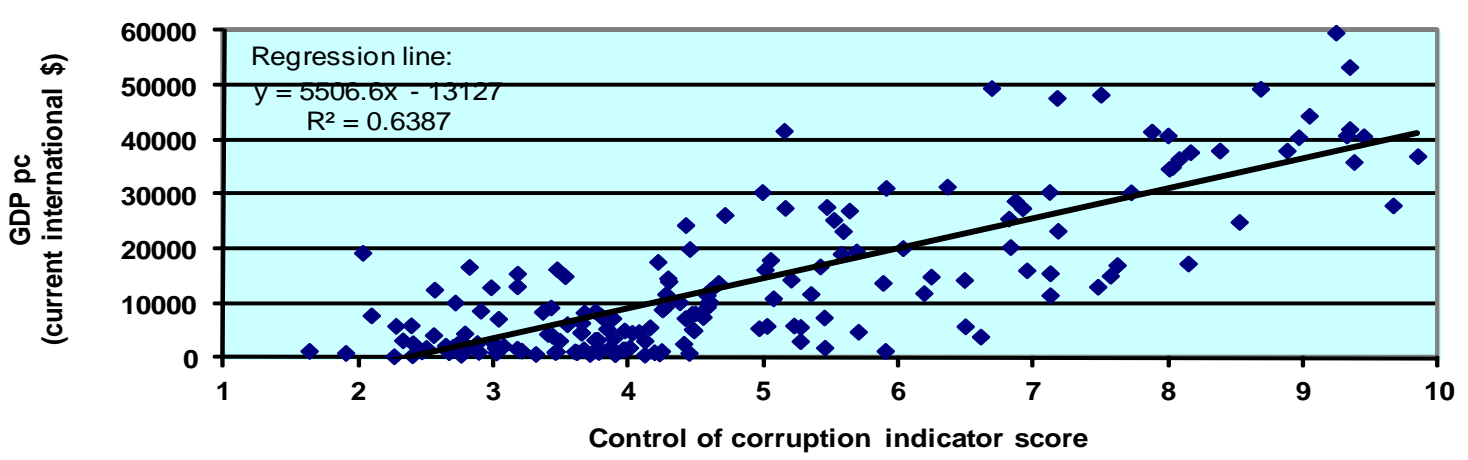

1. The sources for data included in Figure 1 include data from the International Monetary Fund and the World Bank.

Source: OECD (2014), Issues paper on corruption and economic growth, pp. 10-11 
Table 1. Economic and governance rankings of SADC countries

\begin{tabular}{|c|c|c|c|c|c|}
\hline & $\begin{array}{l}2014 \text { UNDP } \\
\text { Human } \\
\text { Develop- } \\
\text { ment Index } \\
\text { (HDI) } \\
\text { (out of } 187 \\
\text { countries) }\end{array}$ & $\begin{array}{c}\text { WEF Global } \\
\text { Competitiveness } \\
\text { Report }^{2} \\
\text { (out of } 148 \\
\text { countries) }\end{array}$ & $\begin{array}{c}2013 \text { World Bank } \\
\text { Doing Business } \\
\text { Ranking }^{3} \\
\text { (out of } 189 \text { countries) }\end{array}$ & $\begin{array}{c}2013 \text { TI } \\
\text { Corruption } \\
\text { Perceptions } \\
\text { Index } \\
\text { (out of } 177 \\
\text { countries) }\end{array}$ & $\begin{array}{l}2012 \text { Worldwide } \\
\text { Governance-- } \\
\text { Control of } \\
\text { Corruption } \\
\text { Indicator }^{5}\end{array}$ \\
\hline Angola & 149 & 142 & 179 & 153 & 8th percentile \\
\hline Botswana & 109 & 74 & 56 & 30 & 79th \\
\hline DR Congo & 140 & $\mathrm{~N} / \mathrm{A}$ & 183 & 154 & 4th \\
\hline Lesotho & 162 & 123 & 136 & 55 & 62nd \\
\hline Madagascar & 155 & 132 & 148 & 127 & 31st \\
\hline Malawi & 174 & 136 & 171 & 91 & 40th \\
\hline Mauritius & 63 & 45 & 20 & 52 & 67th \\
\hline Mozambique & 178 & 137 & 139 & 119 & 33rd \\
\hline Namibia & 127 & 90 & 98 & 57 & 67th \\
\hline Seychelles & 71 & 80 & 80 & 47 & 67th \\
\hline South Africa & 118 & 53 & 41 & 72 & 54th \\
\hline Swaziland & 148 & 124 & 123 & 82 & 52nd \\
\hline Tanzania & 159 & 125 & 145 & 111 & 22nd \\
\hline Zambia & 141 & 93 & 83 & 83 & 46th \\
\hline Zimbabwe & 156 & 131 & 170 & 157 & 5 th \\
\hline SADC averages: & $\begin{array}{l}\text { Avg. rank: } \\
137 / 187\end{array}$ & $\begin{array}{l}\text { Avg. rank: } \\
106 / 148\end{array}$ & $\begin{array}{l}\text { Avg. rank: } \\
118 / 189\end{array}$ & $\begin{array}{l}\text { Avg. rank: } \\
93 / 177\end{array}$ & $\begin{array}{l}\text { Avg. \%ile: } \\
\text { 43rd }\end{array}$ \\
\hline
\end{tabular}

1. The UN Development Programme's Human Development Index is a summary measure of average achievement in key dimensions of human development: a long and healthy life, being knowledgeable and have a decent standard of living. Rankings are out of 187 countries. The 2014 Index data can be found online here: http://hdr.undp.org/en/content/table-1human-development-index-and-its-components

2. The Global Competitiveness Report 2013-2014 assesses the competitiveness landscape of 148 economies. See online here: http://www.weforum.org/reports/global-competitiveness-report-2013-2014

3. The World Bank Group Doing Business ranking provides objective measures of business regulations and their enforcement across 189 economies. See online here: http://www.doingbusiness.org/rankings.

4. The Transparency International Corruption Perceptions Index measures the perceived levels of public sector corruption in 177 countries and territories. See online here: http://cpi.transparency.org/cpi2013/

5. The World Bank's Worldwide Governance Indicators (WGI) project reports aggregate and individual governance indicators for 215 economies over the period 1996-2012, for six dimensions of governance: Voice and accountability, political stability and absence of violence, government effectiveness, regulatory quality, rule of law, and control of corruption. Percentile ranks indicate the percentage of countries worldwide that rank lower than the indicated country, so that higher values indicate better governance scores. See online here: http://info.worldbank.org/governance/wgi/index.aspx\#reports

Governments are also paying closer attention to the wider economic argument for combating corruption. Studies indicate there may be a positive (though not causal) correlation between observed levels of economic output and improvement in the perceived level of corruption in an economy. ${ }^{7}$ Figure 1 illustrates the relationship between perceived levels of corruption and GDP per capita. ${ }^{8} \mathrm{~A}$ recent OECD analysis of this relationship,

7. It has proven difficult to quantify the effect of corruption on economic growth, as there is not a direct relationship between the two variables. For more, see the summary of academic literature on this topic included in the OECD's 2014 "Issues Paper on Corruption and Economic Growth", prepared on behalf of the G20 Anti-Corruption Working Group. (www.oecd.org/g20/topics/anti-corruption/issues-paper-oncorruption-and-economic-growth.htm)

8. The perceived levels of corruption are based on the World Bank's control of corruption indicator, which is one of six governance measurements developed by the World Bank as part of its Worldwide 
undertaken at the request of the G20 Anti-Corruption Working Group, indicates that an improvement in perceived levels of corruption by one standard deviation (two points) is associated with an increase of approximately USD 11,000 in GDP per capita (at 2011 prices).

Indeed, while African economies are among the fastest-growing in the world, the perceived levels of corruption on the continent remain an obstacle to greater foreign direct investment (FDI) and ultimately affects the ability of companies, whether private or stateowned to effectively do business. (See Table 1 for economic and governance rankings for SADC countries.)

\section{Methodology}

This report is based on survey responses from members of the OECD-Southern Africa Network on Governance of State-Owned Enterprises ${ }^{9}$ to a preliminary questionnaire developed by the OECD Secretariat on the SOE Network's behalf. (See Annex 1 for the full text of the questionnaire.) The seven countries that volunteered to participate in the survey are: Botswana, the Democratic Republic of Congo, Malawi, Mozambique, Seychelles, South Africa, and Zimbabwe. Where possible, country inputs are supplemented by publicly available information on the anti-corruption and business integrity measures developed in the jurisdictions that participated in the stocktaking. The results of this report were discussed by SOE Network members at their $5^{\text {th }}$ meeting, which took place in Lusaka, Zambia. ${ }^{10}$

For clarification purposes, this survey applies the definition of SOE included in the Guidelines on the Governance of State-Owned Enterprises in Southern Africa, which narrows the scope of possible SOEs to those that are under central government or federal ownership using a distinct legal form, having a commercial activity, and where the State has effective control through full, majority, or significant minority ownership. ${ }^{11}$

This survey also does not apply a universal definition of "corruption", as there is no universally accepted legal definition. Instead, stocktaking participants were asked to base their responses on the definition of select specific corruption offences as defined in the United Nations Convention against Corruption (UNCAC), ${ }^{12}$ which post-dates the African Union Convention on Preventing and Combating Corruption, and to which all Southern Africa Development Community (SADC) members are Party (see Table 2 and section II.1, below for more on the international anti-corruption legal framework). The UNCAC requires all States Parties to enact certain specific criminal corruption offences via national implementing legislation, if these are not already crimes in a Party's home jurisdiction. In some cases, the implementation of offences is optional, in order to account for differences in domestic law.

Governance Indicators (WGI) project. For more on the WGI project and the control of corruption indicator, see online here: http://info.worldbank.org/governance/wgi/index.aspx\#doc

9. The SOE Network mainly covers the member economies of the SADC: Angola, Botswana, DR Congo, Lesotho, Malawi, Mauritius, Mozambique, Namibia, Seychelles, South Africa, Swaziland, Tanzania, Zambia, and Zimbabwe; plus Kenya.

10. A full record of this meeting is available online here: http://www.oecd.org/daf/ca/5th-soe-southernafrica-meeting-2014.htm

11. See online here: http://www.oecd.org/daf/ca/SOE-Guidelines-Southern-Africa.pdf

12. See online here: www.unodc.org/unodc/en/treaties/CAC/index.html 
Table 2. UNCAC corruption offences

\begin{tabular}{|l|l|l|}
\hline \multicolumn{1}{|c|}{ Offence } & \multicolumn{1}{c|}{ UNCAC Provision } & \multicolumn{1}{c|}{ Requirement to enact } \\
\hline Active and passive domestic bribery & Article 15 & Mandatory criminalisation \\
\hline Active foreign bribery & Article 16.1 & Mandatory criminalisation \\
\hline $\begin{array}{l}\text { Embezzlement, misappropriation or other } \\
\text { diversion of property by a public official }\end{array}$ & Article 17 & Mandatory criminalisation \\
\hline Trading in influence & Article 18 & Optional criminalisation \\
\hline Abuse of functions & Article 19 & Optional criminalisation \\
\hline Illicit enrichment & Article 20 & Optional criminalisation \\
\hline Bribery in the private sector & Article 21 & Optional criminalisation \\
\hline
\end{tabular}

States Parties are also required to criminalise offences committed in support of corruption, including money-laundering (Art. 23) and obstructing justice (Art. 25). A number of additional mandatory provisions are included in the UNCAC in order to facilitate the detection, investigation, prosecution and punishment of bribery and corruption. These measures include, for example, holding companies liable for these crimes (Art. 26), having effective and proportionate sanctions (Art. 30.1), and providing whistle blower protections (Art. 33). Some of these measures are referenced in the country responses, as discussed below. 


\section{PART II}

\section{Policy, legal, and regulatory measures for combating corruption}

\subsection{Overview}

This section of the report focuses on the overall framework for combating corruption in the countries represented in this report: Botswana, DR Congo, Malawi, Mozambique, Seychelles, South Africa, and Zimbabwe. The information in this section draws from country inputs, as well as from publicly available resources, including a 2012 OECD/African Development Bank stocktaking of business integrity and anti-bribery legislation, policies, and practices in 20 African countries. ${ }^{13}$ This section also draws from country reviews and analysis conducted under the auspices of the various international and regional anti-corruption instruments to which SADC members are Party. These instruments, which are legally binding ${ }^{14}$ on States Parties, include:

- $\quad$ SADC Protocol against Corruption (SPAC). ${ }^{15}$ SADC heads of state adopted the SPAC in 2001, and it entered into force in 2005, after it was ratified by two-thirds of SADC membership. The SPAC "aims to promote and strengthen the development, within each Member State, of mechanisms needed to prevent, detect, punish and eradicate corruption in the public and private sector."

- African Union Convention on Preventing and Combating Corruption (AUCPCC). ${ }^{16}$ The AUCPCC is a legally binding regional anti-corruption instrument, which the Assembly of the African Union adopted in 2003 and which entered into force in 2006. The AUCPCC includes provisions on corruption-prevention, ation, and regional cooperation and mutual legal assistance in the investigation and prosecution of corruption crimes. All AUCPCC provisions are mandatory.

- UN Convention against Corruption (UNCAC). ${ }^{17}$ The UNCAC and the OECD AntiBribery Convention (described below) are the only two international legally binding anti-corruption instruments. Adopted in 2003 and entering into force in 2005, the UNCAC is open to all countries and provides a broad range of obligatory and voluntary provisions for detecting, investigating, prosecuting and punishing corruption crimes.

13. OECD/African Development Bank (2012), Stocktaking of Business Integrity and Anti-Bribery Legislation, Policies and Practices in Twenty African Countries, OECD Publishing

14. As legally binding instruments, States Parties agree to implement the obligatory provisions contained therein via national implementing legislation.

15. See online here: www.sadc.int/documents-publications/show/

16. See online here: www.au.int/en/sites/default/files/AFRICAN UNION CONVENTION PREVENTING COMBATING CO RRUPTION.pdf

17. See online here: www.unodc.org/unodc/en/treaties/CAC/ 
- OECD Convention on Combating Bribery of Foreign Public Officials in International Business Transactions (OECD Anti-Bribery Convention). ${ }^{18}$ The OECD Anti-Bribery Convention focuses on a specific form of corruption: the bribery of foreign public officials in international business transactions. It requires States Parties to e this form of corruption, and provides for a host of related measures to facilitate States Parties' effective enforcement of their laws against this crime. South Africa is the only SADC member that is Party to this instrument.

The status of the signature and/or ratification of these international and regional anticorruption instruments by the countries participating in this stocktaking survey are included in Table 3. Table 4 summaries these countries' efforts to implement these instruments via national implementing legislation.

Table 3. Status of SADC signature and ratification of international and regional anti-corruption instruments

\begin{tabular}{|c|c|c|c|c|c|c|c|c|}
\hline \multirow[b]{2}{*}{ Country } & \multicolumn{2}{|c|}{\begin{tabular}{|c|} 
SADC Protocol \\
against Corruption
\end{tabular}} & \multicolumn{2}{|c|}{$\begin{array}{l}\text { AU Convention on } \\
\text { Preventing and } \\
\text { Combating } \\
\text { Corruption }\end{array}$} & \multicolumn{2}{|c|}{$\begin{array}{c}\text { UN Convention } \\
\text { against Corruption }\end{array}$} & \multicolumn{2}{|c|}{$\begin{array}{l}\text { OECD Anti-Bribery } \\
\text { Convention }\end{array}$} \\
\hline & Signed & Ratified & Signed & Ratified & Signed & Ratified & Signed & Ratified \\
\hline Angola & 2001 & 2005 & 2007 & - & 2003 & 2006 & - & - \\
\hline Botswana & 2001 & 2001 & - & - & - & 2011 & - & - \\
\hline DR Congo & 2001 & 2008 & 2003 & - & - & 2010 & - & - \\
\hline Lesotho & 2001 & 2003 & 2004 & 2004 & 2005 & 2005 & - & - \\
\hline Madagascar & - & - & 2004 & 2004 & 2003 & 2004 & - & - \\
\hline Malawi & 2001 & 2002 & - & 2007 & 2004 & 2007 & - & - \\
\hline Mauritius & 2001 & 2002 & 2004 & - & 2003 & 2004 & - & - \\
\hline Mozambique & 2001 & 2007 & 2003 & 2006 & 2004 & 2008 & - & - \\
\hline \begin{tabular}{|l|} 
Namibia \\
\end{tabular} & 2001 & 2005 & 2003 & 2004 & 2003 & 2004 & - & - \\
\hline Seychelles & 2001 & - & - & 2008 & 2004 & 2006 & - & - \\
\hline South Africa & 2001 & 2003 & 2004 & 2005 & 2003 & 2004 & 2007 & 2007 \\
\hline Swaziland & 2001 & 2006 & 2004 & - & 2005 & - & - & - \\
\hline Tanzania & 2001 & 2003 & 2003 & 2005 & 2003 & 2005 & - & - \\
\hline Zambia & 2001 & 2003 & 2005 & 2007 & 2003 & 2007 & - & - \\
\hline Zimbabwe & 2001 & 2004 & 2003 & 2006 & 2004 & 2007 & - & - \\
\hline
\end{tabular}

Sources: Chinhamo, Obert and Alouis Munyaradzi Chaumba (2012), Progress on Signature and Ratification of Anti-Corruption Instruments by SADC Member States: Who is Lagging Behind among SADC Member States?, Anti-Corruption Trust of

Southern Africa and the Non- State Actors Forum of Zimbabwe, and the websites of each of the SADC Protocol against Corruption (http://www.sadc.int/documents-publications/show/795), African Union Convention (www.au.int/en/sites/default/files/Corruption.pdf), the UNCAC (https://www.unodc.org/unodc/en/treaties/CAC/signatories.html), and the OECD Anti-Bribery Convention (http://www.oecd.org/daf/anti-bribery/WGBRatificationStatus.pdf).

18. See online here: www.oecd.org/daf/anti-bribery/oecdantibriberyconvention.htm 
Table 4. National implementing legislation for specific UNCAC corruption offences in Botswana, DR Congo, Malawi, Mozambique, Seychelles, South Africa, \& Zimbabwe

\begin{tabular}{|c|c|c|c|c|c|c|c|}
\hline & & \multicolumn{6}{|c|}{ National implementing legislation (as of October 2014) } \\
\hline Offence & Botswana & DR Congo & Malawi & $\begin{array}{c}\text { Mozam- } \\
\text { bique }\end{array}$ & Seychelles & $\begin{array}{l}\text { South } \\
\text { Africa }\end{array}$ & Zimbabwe \\
\hline $\begin{array}{l}\text { Active and } \\
\text { passive } \\
\text { domestic } \\
\text { bribery } \\
\text { (UNCAC } \\
\text { Art. 15) }\end{array}$ & $\begin{array}{l}\text { Corruption \& } \\
\text { Economic } \\
\text { Crime Act } \\
\text { (CECA) }\end{array}$ & $\begin{array}{l}\text { Law No. } \\
05 / 006\end{array}$ & $\begin{array}{l}\text { Corrupt } \\
\text { Practices } \\
\text { Act (CPA) }\end{array}$ & $\begin{array}{l}\text { Law Nr. } \\
6 / 2004, \\
\text { Anti- } \\
\text { Corruption } \\
\text { Law (ACL) } \\
\text { Penal Code }\end{array}$ & Penal Code & $\begin{array}{l}\text { Prevention } \\
\text { and } \\
\text { Combatting } \\
\text { of Corrupt } \\
\text { Activities } \\
\text { Act } \\
\text { (PRECCA) }\end{array}$ & $\begin{array}{l}\text { Criminal } \\
\text { Law } \\
\text { (Codification } \\
\text { and Reform) } \\
\text { Act (CLA) }\end{array}$ \\
\hline $\begin{array}{l}\text { Active } \\
\text { foreign } \\
\text { bribery } \\
\text { (UNCAC } \\
\text { Art. 16.1) }\end{array}$ & Unknown & Unknown & Unknown & Unknown & Unknown & PRECCA & Unknown \\
\hline $\begin{array}{l}\text { Embezzle- } \\
\text { ment, } \\
\text { misappropri } \\
\text { ation or } \\
\text { other } \\
\text { diversion of } \\
\text { property by } \\
\text { a public } \\
\text { official } \\
\text { (UNCAC } \\
\text { Art. 17) }\end{array}$ & $\begin{array}{l}\text { CECA } \\
\text { Penal Code }\end{array}$ & $\begin{array}{l}\text { Law No. } \\
\text { 05/006 }\end{array}$ & CPA & Unknown & Unknown & PRECCA & CLA \\
\hline $\begin{array}{l}\text { Trading in } \\
\text { influence } \\
\text { (UNCAC } \\
\text { Art. 18) }\end{array}$ & CECA & Unknown & CPA & Unknown & Unknown & PRECCA & Unknown \\
\hline $\begin{array}{l}\text { Abuse of } \\
\text { functions } \\
\text { (UNCAC } \\
\text { Art. 19) }\end{array}$ & $\begin{array}{l}\text { CECA } \\
\text { Penal Code }\end{array}$ & $\begin{array}{l}\text { Law No. } \\
\text { 05/006 }\end{array}$ & CPA & Unknown & Penal Code & PRECCA & CLA \\
\hline $\begin{array}{l}\text { Illicit enrich- } \\
\text { ment } \\
\text { (UNCAC } \\
\text { Art. 20) }\end{array}$ & CECA & Unknown & Unknown & Unknown & Unknown & PRECCA & Unknown \\
\hline $\begin{array}{l}\text { Bribery in } \\
\text { the private } \\
\text { sector } \\
\text { (UNCAC } \\
\text { Art. 21) }\end{array}$ & $\begin{array}{l}\text { CECA } \\
\text { Penal Code }\end{array}$ & $\begin{array}{l}\text { Law No. } \\
\text { 05/006 }\end{array}$ & CPA & Unknown & Penal Code & PRECCA & Unknown \\
\hline
\end{tabular}

\subsection{Country profiles}

\subsubsection{Botswana}

Botswana ratified the SADC Protocol against Corruption in 2001, acceded to the UN Convention against Corruption in June 2011, but has not acceded to the African Union Convention on Preventing and Combating Corruption. 
Botswana's Government recognized the risk corruption poses to the country's economy ${ }^{19}$ with the 1994 enactment of the Corruption and Economic Crime Act, ${ }^{20}$ which established in September 1994 the Directorate on Corruption and Economic Crime (DCEC) ${ }^{21}$ The DCEC an operationally autonomous law enforcement agency charged with a three-pronged mandate to: (1) investigate allegations of corruption and economic crime, as well as suspicious transactions and to share investigative results with the Directorate of Public Prosecutions (DPP) for possible prosecution; (2) prevent corruption in the public sector by auditing government and state-owned institutions; and (3) to raise awareness of the risks of corruption through public education activities. In support of these functions, DCEC has also worked to establish Corruption Prevention Committees (CPCs) in government ministries and departments and anti-corruption units in ministries that were considered especially prone to the risks of corruption, including the Ministry of Infrastructure, Science and Technology, the Ministry of Finance and Development Planning, and the Ministry of Education and Skills Development. ${ }^{22}$

The legal foundation for Botswana's anti-corruption efforts includes the following legislative acts:

- The aforementioned Corruption and Economic Crime Act (1994) established the DCEC (Parts II and III) and es specific corrupt acts and practices (Part IV), including active and passive domestic bribery (Sections 24 - 27 and Section 29); embezzlement (Section 33); trading in influence (Section 25A and 29); abuse of functions (Section 24A); illicit enrichment (Section 34); private sector bribery (Section 28); and obstruction of justice (Section 18).

- The Penal Code also es certain corruption crimes, including embezzlement, misappropriation or the diversion of property by a public official (Sections 102, 103, 269, 276-279, 322, 324-325); the falsification of books and records (Sections 322323); abuse of functions (Section 104); private sector bribery (Section 384); private sector embezzlement (Section 322); and obstruction of justice (Sections 109, 120 and 123).

- The Proceeds of Serious Crime Act (1990) es the laundering of proceeds of serious offences.

- The Public Procurement and Asset Disposal Act (2001) ${ }^{23}$ aims to ensure an open, fair, and transparent tendering according to commercial practices. The Act

\footnotetext{
19. Kuris, Gabriel, "Managing Corruption Risks: Botswana Builds an Anti-Graft Agency, 1994 - 2012," Innovations for Successful Societies, Princeton University, 2013 (www.princeton.edu/successfulsocieties/content/data/policy note/PN id233/Policy Note ID233.pdf)

20. www.track.unodc.org/LegalLibrary/LegalResources/Botswana/Laws/ BotswanaCorruptionandEconomicCrimeAct1994.pdf

21. www.gov.bw/en/Ministries--Authorities/Ministries/State-President/Department-of-Corruption-andEconomic-Crime-DCEC/About-the-DCEC1/About-the-DCEC/

22. Presentation by Rose Nunu Seretse, DCEC Director, accessed via the African Governance Assessment Platform (www.afrigap.org//MG/ppt/seretse.ppt)

23. www.ppadb.co.bw/documents/PPAD Act revised.pdf
} 
established the Public Procurement and Asset Disposal Board, ${ }^{24}$ an SOE charged with regulating public procurement matters in Botswana.

Botswana's responses to the stocktaking questionnaire add that there is no corporate liability in Botswana. Only natural persons can be held liable for corruption crimes. In cases where bodies corporate are found to have been involved in criminal activity, Botswana's authorities state that prosecutions target the leadership of the concerned entities or the culpable officials. Authorities have also reported that there is currently no law on whistleblowing and whistle-blower protections in Botswana, but one is being drafted. ${ }^{25}$

\subsubsection{Democratic Republic of Congo (DR Congo)}

The DR Congo ratified the SADC Protocol against Corruption in 2008, signed (but did not ratify) the African Union Convention on Preventing and Combating Corruption in 2003 and ratified the UNCAC in 2010.

Corruption remains a serious impediment to DR Congo's ability and capacity to extricate itself from years of devastating violence and instability. DR Congo ranks nearly last in the World Bank's annual Doing Business Index (183rd out of 189 countries) and is perceived as one of the most corrupt countries in the world, according to the Transparency International Corruption Perceptions Index, ranking 154 out of 177 countries. On the ground, the Government has stated that more than half of DRC's population faces corruption in their daily lives and that at least USD 15 billion are lost to corruption and not collected in taxes. This has negatively impacting the Government's ability to provide public services. The International Monetary Fund estimates that, as a result of pervasive poverty and gross mismanagement of public funds and natural resources, the DR Congo will most likely not reach any of the Millennium Development Goals by the 2015 deadline. ${ }^{26}$

Since the DR Congo first held successful elections in 2006, the successive administrations have stated that fighting corruption is a Government priority. In 2009, the Government adopted a National Strategy Document for Combating Corruption, which recommended a set of legal and institutional anti-corruption reforms. As part of this effort, a draft Law on the Prevention and Suppression of Corruption in the Democratic Republic of Congo was passed in Parliament. President Joseph Kabila also launched in 2009 a "zerotolerance" policy against corruption, which included establishing a Financial Intelligence Unit to combat money laundering and the misappropriation of public funds. ${ }^{27}$

24. See online here: www.ppadb.co.bw. The PPADB reports to the Ministry of Finance and Development Planning.

25. See page 5 of Botswana's UNCAC Review self-assessment (www.unodc.org/documents/treaties/UNCAC/SAReport/2013 0828 Botswana UNCAC Review SACL.pdf)

26. IMF (2014), Democratic Republic of the Congo: Staff Report for the 2014 Article IV Consultation, 20 May 2014 (www.imf.org/external/pubs/ft/scr/2014/cr14301.pdf), p. 4. See also: African Development Bank/African Development Fund (2013), Democratic Republic of Congo: 2013-2017 Country Strategy Paper; Bertelsmann Stiftung's Transformation Index (BTI) 2014, Democratic Republic of the Congo Country Report (www.btiproject.org/fileadmin/Inhalte/reports/2014/pdf/BTI\%202014\%20Congo\%20DR.pdf)

27. United States Department of State Bureau of Democracy, Human Rights and Labor (2011), Country Reports on Human Rights Practices for 2011: Democratic Republic of Congo (www.state.gov/documents/organization/186395.pdf), p. 28. 
The legal foundation ${ }^{28}$ for the DRC's anti-corruption efforts includes the following legislative acts:

- Law No. 05/006 of 29 March $2005,{ }^{29}$ which amends Art. 147 of the Penal Code, es active and passive domestic bribery (Art. 147.4 and 147bis.1-2), private sector bribery (Art. 147bis.3), abuse of function (Art. 147bis.4), and the embezzlement, misappropriation or other diversion of property by a public official (Art. 147bis.5).

- Law No. 04/16 of 19/7/2004 es money laundering and terrorism financing and created the DRC's financial intelligence unit, the Cellule Nationale des Renseignements Financiers (CENAREF).

- Law No. 10/010 of 27 April 2010 regulates public procurement procedures.

- Legislative Decree No. 017/2002 of 3 October 2002 establishes a Code of Conduct for Public Officers of the State. The code includes requires public officials to declare their assets and also establishes a public body to ensure the Code of Conduct's implementation.

- Presidential ordinance No. 087-323 of 15 September 1987 established the Inspection Générale des Finances (IGF), the DRC's state audit institution. ${ }^{30}$

The DR Congo reported that its anti-corruption framework is further complemented by laws to increase transparency in investments in the DRC's lucrative mining and forestry sectors; the DRC's membership in the Organisation pour l'Harmonisation en Afrique du Droit des Affaires ("Organisation for the Harmonisation of Business Law in Africa"; OHADA); and adherence to the Extractive Industries Transparency Initiative (EITI).

Legal entities, including SOEs, can be held administratively liable under Congolese law.

\subsubsection{Malawi}

Malawi ratified the SADC Protocol against Corruption in 2002 and ratified both the African Union Convention on Preventing and Combating Corruption and the UN Convention against Corruption in 2007.

Malawi's current anti-corruption framework dates back to 2004, when the Malawi Government, under President Bingu Wa Mutharika, declared a zero-tolerance approach to corruption. This approach was formalised in February 2007 with a Declaration on Zero

28. For note, the DR Congo authorities note that, in 2003, the Government established under the 2003 transitional Constitution the Commission de l'Ethique et de la Lutte contre la Corruption (CELC; "Ethics and Anti-Corruption Commission"). However, the CELC was ineffective and was later disbanded and not included in the 2006 Constitution. (See also: Kodi, Muzong (2008), Corruption et gouvernance en $R D C$ durant la Transition (2003-2006), Institute for Security Studies

[http://www.issafrica.org/uploads/MONO153FUOLL.PDF] and : www.track.unodc.org/LegalLibrary/LegalResources/Democratic\%20Republic\%20of\%20Congo/Authoriti es/Democratic\%20Republic\%20of\%20Congo\%20Authorities\%20.docx)

29. See online here: www.leganet.cd/Legislation/DroitPenal/divers/loi.05.29.05.2005.pdf

30. See also, EITI (2012), Rapport ITIE-RDC 2010 (eiti.org/files/Gabon/RAPPORT\%20ITIE\%202010\%20\%2024 $01 \quad 013 \% 20$ INTERNET.pdf) 
Tolerance on Corruption. Since 2004, the Government has taken a number of policy and legislative steps to strengthen the country's anti-corruption framework. In 2005, for example, the Government conducted a Governance and Corruption Baseline Survey to identify corruption problem areas. The survey showed that nine out of 10 Malawians perceived corruption as a serious problem and a major impediment to doing business in Malawi and to Malawi's economic development. A particular problem highlighted by the survey was bribery of Malawi's public officials, who acknowledged that bribes represent nearly a quarter of their salaries. As a result, Malawi's citizens felt that public institutions (including, for example, the state-owned Malawi Housing Corporation) were failing to properly deliver public services. ${ }^{31}$

To address this challenge, the Government adopted in 2008 a National Anti-Corruption Strategy, ${ }^{32}$ which aims to provide a holistic approach to the fight against corruption in Malawi. It incorporates the various anti-corruption actors in Malawi, including the Anti-Corruption Bureau, the Business Action against Corruption and the Civil Society Action against Corruption. Its focus is the development of a National Integrity System (NIS), which targets eight sectors, requiring each to establish Institutional Integrity Committees, which will develop and implement sector-specific anti-corruption plans. The eight sectors are: the Government's executive, judicial, and legislative branches, civil society, the private sector, the media, traditional leaders, and faith-based organisations. The NIS also requires all stakeholders to develop and implement ethical codes of conduct. Implementation of the NIS is monitored by a multi-stakeholder National Integrity Committee, though the ultimate responsibility for the success of Malawi's National Anti-Corruption Strategy lies with the AntiCorruption Bureau.

The National Anti-Corruption Strategy identifies the following acts and practices as constituting corruption: the offering and/or soliciting of bribes; extortion; the abuse of discretion (or trading in influence); abuse of office; and conflicts of interest. The legal foundation for Malawi's anti-corruption efforts includes the following legislative acts:

- The Corrupt Practices Act (1995), ${ }^{33}$ which, among other measures, established the Anti-Corruption Bureau (Part II) and es specific corrupt acts and practices (Part IV), including active and passive domestic bribery (Art. 24); embezzlement, misappropriation or other diversion of property by a public official (Art. 25B.3); trading in influence (Art. 27.4); abuse of functions (Arts. 25 and 25A); illicit enrichment (Art. 32); and bribery in the private sector (Art. 26). ${ }^{34}$ The Act also provides for protection of whistle blowers and other informers (Art. 51A).

31. World Bank, "Good-Practice Note: Governance and Anti-Corruption Innovations in the Malawi Social Action Fund Project", No. 131/June 2010, p. 1 (www.wdronline.worldbank.org/bitstream/handle/10986/11088/639050BRI0Gove00Box0361531B0PUB LIC0.pdf?sequence $=1$ )

32. See online here: www.acbmw.com/wpcontent/downloads/NATIONAL ANTI CORRUPTION STRATEGY.pdf

33. See online here: www.malawilii.org/files/mw/legislation/consolidatedact/7:04/corrupt practices act pdf 90548.pdf

34. Malawi's responses to the stocktaking questionnaire add that the offence of embezzlement of property in the private sector is covered under that country's Company Law and Penal Code. 
- The Public Procurement Act (2003), ${ }^{35}$ which established the Office of the Director of Public Procurement (Part II) and sets forth procedures for procurement projects financed by public funds.

- The Public Audit Act (2003), which gives Malawi's Auditor General the authority to review the overall management of public finances, via audits of public bodies, including SOEs.

- The Public Finance Management Act (2003), which forms the framework for public financial management in Malawi, including requirements to report on fiscal policy and budgetary issues and the responsibilities of the Minister of Finance.

- The Money Laundering, Serious Crimes and Financing of Terrorism Act (2006), ${ }^{36}$ which es the laundering of proceeds from "serious crime", ${ }^{37}$ including the corruption offences defined in the Corrupt Practices Act, and established Malawi's Financial Intelligence Unit (Part II).

- The Public Officers (Declaration of Assets, Liabilities, and Business Interests) Act (2013), which requires certain public officials to declare their assets ${ }^{38}$ and established an Office of the Director of Public Officers' Assets, Liabilities and Business Interests Declarations (Part III).

Malawi's authorities add that bodies corporate may be held liable for these offences, either criminally or administratively, depending on the law. ${ }^{39}$

\subsubsection{Mozambique}

Mozambique ratified the SADC Protocol against Corruption in 2007, ratified the African Union Convention on Preventing and Combating Corruption in 2006, and ratified the UN Convention against Corruption in 2008.

The Government of Mozambique has declared fighting corruption a top priority in successive governance programmes. This policy focus was concretised in 2004 with the

35. See online here: www.malawilii.org/files/mw/legislation/act/2003/8/ppa2003215 pdf 43350.pdf

36. See online here: www.malawilii.org/files/mw/legislation/act/2006/11/money laundering act 2006 pdf 19156.pdf

37. Serious crimes are defined in Malawi's anti-money laundering legislation as any offence for which the maximum penalty is death or imprisonment for life or a prison term of not less than 12 months. Art. 34 of the Corrupt Practices Act states that the penalty for committing any of the corruption offences outlined in Part IV of the act is imprisonment for twelve years.

38. Public officials to whom the Act applies are listed in the First Schedule of the Act. See the draft version of this Act, submitted to Parliament in October 2013, online here: www.parliament.gov.mw/docs/bills/B21 2013.pdf

39. For example, bodies corporate may be held criminally liable under the Money Laundering, Serious Crimes and Financing of Terrorism Act. See also: Chalunda, McSyd Hubert, "Corporate Crime and the Criminal Liability of Corporate Entities", UNAFEI Resource Material Series No. 76, December 2008 (www.unafei.or.jp/english/pdf/RS No76/No76 08PA Chalunda.pdf). 
adoption of Law Nr. 6/2004 of 17 June, The Anti-Corruption Law, ${ }^{40}$ described in greater detail below. The Law is Mozambique's first corruption-specific legislation, and it established the Central Office for Combating Corruption, or the GCCC ("Gabinete Central de Combate à Corrupçã"), which has been operational since 2006. Subordinate to the General Prosecutor, the GCCC is charged with implementing the Government's anti-corruption policy and enforcing its Anti-Corruption Law via its headquarters in the capital city of Maputo, its northern provincial office in Nampula province, in its central provincial office in Sofala province, and in the Province of Inhambane.

Mozambique's anti-corruption efforts were further developed in 2010 when the Government submitted to Parliament an "Anti-Corruption legislative package", which contained a set of legislative proposals. These proposals were meant to bring Mozambique's legal framework more closely in line with the standards set forth in the African Union Convention and the SADC Protocol on Corruption. Mechanisms to address conflict of interests, protect whistle blowers, guarantee ethical behaviour in the public administration, as well as e corruption practices which were not ed in existing legislation were part of the package. ${ }^{41}$ A number of these laws were passed in 2012 and are included below, as they make up an important part of Mozambique's legal foundation for combating corruption: ${ }^{42}$

- Law Nr. 6/2004, The Anti-Corruption Law, establishes domestic bribery (both active and passive) as an offence (Articles 7 and 9). It also created the Central Office for Combating Corruption (GCCC). (The powers of the GCCC were later strengthened with the passage of Law Nr. 14/2012, Organic Law of the Public Ministry and the Statute of Public Prosecutors.)

- Chapter IX of the Penal Code (1886) es both passive and active bribery of and by public officials and members of the judiciary (Articles 318-322).

- Law Nr. 14/2013, the Law on Prevention and Fight against Money Laundering and Terrorism Financing, es the laundering of the proceeds of crime.

- Law Nr. 16/2012, the Public Probity Law, was originally conceived of as a code of ethics for public servants. It establishes legal grounds regarding public morality and respect for the public good. The law includes provisions that define conflicts of interest for public officials and establishes an independent Ethics Commission.

40. An unofficial link to the law can be found online here: www.issafrica.org/cdct/mainpages/pdf/Corruption/Legislation/Mozambique/Mozambique\%20Anticorruption\%20mechanisms.pdf

41. See also: Martini, Maira. "Overview of corruption and anti-corruption in Mozambique", U4 AntiCorruption Resource Center, March 2012 (http://www.u4.no/publications/overview-of-corruption-andanti-corruption-in-mozambique/)

42. As of April 2013, further legislative changes were pending, including revisions to the Penal Code and Criminal Procedure Code to harmonize these laws those submitted in the Anti-corruption legislative package, as well as to bring Mozambique's laws closer in line with UNCAC requirements. See also: "Republic of Mozambique: APRM National Forum - Progress Report on the Implementation of the National APRM Programme of Action, 2010-2012" (April 2013) (aprm-au.org/document/mozambiqueaprm-progress-report-english-version), pp. 30-31; and Pereira, Pedro Gomes and João Carlos Trindade, "Overview and Analysis of the Anti-Corruption Legislative Package of Mozambique: Legal Analysis", Basel Institute on Governance, 14 February 2012 (www.baselgovernance.org/fileadmin/docs/publications/commissioned studies/Mozambique Legal an alysis.pdf) 
- Law Nr. 15/2012, the Law for the protection of the rights and interests of victims, whistle blowers, witnesses, declarants and experts in criminal proceedings, also established the Central Office for the Protection of the Victim.

- Decree Nr. 15/2010, the Regulation of the Hiring of Public Works Contractors, the Supply of Goods, and Provision of Services to the State, regulates public procurement procedures in Mozambique.

\subsubsection{Seychelles}

Seychelles signed the SADC Protocol against Corruption in 2001, but has not yet ratified it. It ratified the African Union Convention on Preventing and Combating Corruption in 2008 and the UN Convention against Corruption in 2006.

Since 2008, the Seychellois Government under current President Colonel James Michel has implemented a programme of reform to improve public sector governance. These reforms include a focus on holding public institutions more accountable and assessing the role of SOEs in the economy, their management, and their wage structure (see section 2 below). ${ }^{43}$ These efforts have continued, as evidenced, for example, by Seychelles' June 2014 application to join the Extractive Industries Transparency Initiative (EITI) to strengthen transparency in financial reporting in the country's petroleum sector. ${ }^{44}$

Public bodies charged with governance and anti-corruption include the Office of the Ombudsman, which was established under the Constitution of the Republic of Seychelles in 1993 and may investigate any public authority in the country; ${ }^{45}$ the Attorney General's Office, charged with ensuring the accountability and proprietary of public funds ${ }^{46}$ and the Financial Intelligence Unit (FIU), which operates as a unit within the Central Bank of Seychelles and focuses on anti-money laundering and combating the financing of terrorism. The Government estimates that the FIU conducts approximately 500 preliminary money-laundering investigations per year, with about 50 potential cases taken to court or prosecuted.

The legal foundation for Seychelles' anti-corruption efforts includes the following legislative acts:

43. World Bank (2014), "International Bank for Reconstruction and Development Program Document on a Proposed Loan in the Amount of US\$7.0 Million to the Republic of Seychelles for the Third Sustainability and Competitiveness Development Policy Loan, Report No. 83120-SC", August 29, 2014 (www.wds.worldbank.org/external/default/WDSContentServer/WDSP/IB/2014/09/11/000350881 2014 0911085245/Rendered/PDF/831200PGD0P1460C0disclosed090110140.pdf), p. 9.

44. EITI (2014), "Extractive Industries Transparency Initiative Candidature Application Form: Seychelles," June 2014

(eiti.org/files/Seychelles\%20EITI\%20Candidature\%20APPLICATION\%20June\%2011\%202014\%20\%2 83\%29\%20\%283\%29.pdf)

45. See online here: http://track.unodc.org/LegalLibrary/LegalResources/Seychelles/Authorities/Seychelles\%20Authorities.p df

46. See online here: www.oag.sc/about-us/vision-and-mission 
- The Penal Code $(1955)^{47}$ es certain corrupt acts, including domestic active and passive bribery (Art. 91) and extortion (Art. 92); abuse of office (Art. 96); and private corruption (Art. 373).

- The Anti-Money Laundering (Criminal) Act $(2006)^{48}$ es the laundering of the proceeds of crime, including the corruption offences provided in Chapter $\mathrm{X}$ and XXXVIII of the Penal Code. ${ }^{49}$ The Proceeds of Crime (Civil) Act (2008) supports anti-money laundering efforts in Seychelles by providing for the freezing and civil confiscation of criminal assets. ${ }^{50}$

- The Public Procurement Act (2014) established the Procurement Oversight Unit and the National Tender Board, which together promote integrity, fair competition, and good governance in Seychelles' public procurement system.

- The Public Officers Ethics Act $(2008)^{51}$ provides for a code of conduct and ethics for civil servants, including SOE employees. It requires financial declarations and prohibits conflicts of interest. The Act is enforced by the Public Officers Ethics Commission, which developed in 2009 a Code of Conduct and Ethics handbook for Seychellois public officials.

\subsubsection{South Africa ${ }^{52}$}

South Africa ratified the SADC Protocol against Corruption in 2003 and the African Union Convention on Preventing and Combating Corruption and the UN Convention against Corruption in 2004. South Africa is the only SADC Member that is a State Party to the OECD Anti-Bribery Convention, which it ratified in 2007.

South Africa's current anti-corruption framework was borne out of an initiative that began in 2001, when the Cabinet decided to fast-track Government efforts to tackle corruption. To this end, the Government established a National Anti-Corruption Forum ${ }^{53}$ to coordinate and integrate the Government's anti-corruption work and to develop a strategy for sustainably preventing and combating corruption. Cabinet approved the resulting Public Service Anti-

47. See online here: http://greybook.seylii.org/se/CAP158\#!fragment/zoupio- Toc384202616

48. As amended in 2008, 2010, 2012, and 2014. See online here: http://greybook.seylii.org/se/CAP9A

49. See: Eastern and Southern Africa Anti-Money Laundering Group (2008), "Mutual Evaluation Report, Anti-Money Laundering and Combating the Financing of Terrorism: Republic of Seychelles", ESAAMLG 2009, p. 38 (www.esaamlg.org/userfiles/Seychelles Mutual Evaluation Report.pdf)

50. See online here: http://greybook.seylii.org/se/2008-19. See also: ESAAMLG, "Seychelles: National Strategy for Anti-Money Laundering \& Combating the Financing of Terrorism," September 2010 (www.esaamlg.org/userfiles/Seychelles AML CFT National Strategy.pdf)

51. See online here: $\underline{\text { http://greybook.seylii.org/se/2008-14 }}$

52. This section is complemented by the findings of the peer reviews of South Africa's implementation of the UN Convention against Corruption (www.unodc.org/documents/treaties/UNCAC/CountryVisitFinalReports/2013 0509 South Africa Fin al Country Review Report.pdf) and the OED Anti-Bribery Convention (www.oecd.org/daf/antibribery/southafrica-oecdanti-briberyconvention.htm), as well as the FATF Mutual Evaluation Report Anti-Money Laundering and Combating the Financing of Terrorism - South Africa, 26 February 2009 (www.fatf-gafi.org/media/fatf/documents/reports/mer/MER\%20South\%20Africa\%20full.pdf)

53. The Forum, which includes representatives from government, civil society and the private sector, met approximately every two years until 2011. 
Corruption Strategy in early 2002. These efforts translated into the adoption of a legal anticorruption framework that includes:

- Prevention and Combating of Corrupt Activities Act ${ }^{54}$ ('PRECCA') creates a general offence of corruption (Section 3); es passive and active domestic bribery (Section 4.1); active foreign bribery (Section 5.1); embezzlement (Section 4.2.g); trading in influence and abuse of function (Section 3); and private sector bribery (Section 3). PRECCA also establishes an administrative mechanism for addressing the problem of illicit enrichment (Section 23).

- Financial Intelligence Centre Act of 2001 (amended by the Financial Intelligence Centre Amendment Act, 2008) established the Financial Intelligence Centre (FIC), an administrative unit under the supervision of the Ministry of Finance responsible for receiving suspicious transaction reports from financial institutions and businesses as required under South Africa's anti-money laundering regime.

- Protected Disclosures $\mathrm{Act}^{55}$ provides protection for public and private sector employees who report unlawful or irregular conduct of an employer or an employee of that employer

- The Prevention of Organised Crimes Act of 1998 es money-laundering, and the offence covers proceeds from all unlawful activities, including the PECCA corruption offences.

- The Public Finance Management Act of $1999^{56}$ establishes a national treasury, introduces uniform treasury norms and standards, prescribes measures to ensure transparency and expenditure control in all spheres of government, and sets the operational procedures for borrowing, guarantees, procurement and oversight over the various national and provincial revenue funds. It includes a requirement for government departments to undergo risk assessments and to develop fraud prevention plans.

This framework is supported by an institutional capacity that, according to South African authorities, is reaching levels of maturity and efficiency that have provided the country with the ability to more effectively combat corruption. These institutions include:

- The Anti-Corruption Task Team (ACTT), which is an interdepartmental body established in 2010 to fast-track high-priority and high-profile corruption cases. Its Principal Committee includes the head of the Directorate of Priority Crime Investigation (DPCl), the National Director of Public Prosecutions, and the Head of the Special Investigating Unit.

- The DPCl was established in 2009 as an independent directorate within the South African Police Service responsible for the combating, investigation and prevention of national priority crimes, such as serious organised crime, serious commercial crime

54. See online here: www.justice.gov.za/legislation/acts/2004-012.pdf

55. See online here: www.justice.gov.za/legislation/acts/2000-026.pdf

56. See online here: www.treasury.gov.za/legislation/pfma/ 
and serious corruption, as per the South African Police Service Act, 1995 as amended. ${ }^{57}$

- The National Prosecuting Authority (NPA), established under Section 179 of the Constitution and further regulated under the National Prosecuting Authority Act 1998, the NPA is the centralised prosecuting authority. Its functions and duties are to institute and conduct criminal proceedings on behalf of the State, and to carry out any necessary functions incidental to instituting such criminal proceedings.

- The Specialised Commercial Crimes Unit (SCCU), which is part of the within the National Prosecuting Authority of South Africa (NPA), is responsible for the prosecution of complex commercial crime cases under PRECCA. SCCU's 2012 Strategic Plan prioritises corruption cases. The Special Investigating Unit (SIU) is an independent statutory body established under the 1996 Special Investigating Units and Special Tribunal Act with the primary mandate to recover and prevent financial losses to the State caused by acts of corruption, fraud, and maladministration. The SIU has powers to subpoena, search, seize, and interrogate witnesses and to take civil action to correct wrongdoing that it uncovers in its investigations. ${ }^{58}$

- The Public Protector is appointed by the President and is independent of Government. The Public Protector's office investigates public complaints, including with respect to corruption against government agencies and officials.

Regarding corporate liability, South African authorities explained in the context of reviews of South Africa's implementation of the OECD Anti-Bribery Convention that Section 2 of the Interpretation act 1957 provides that South African law is applicable to individuals and legal persons. It implies that PRECCA's offences can be applied to both natural and legal persons. The point of departure for holding a company criminally liable in South Africa is more specifically section 332(1) of the Criminal Procedure Act, 1997, which provides for the prosecution of "corporations and members of associations".

\subsubsection{Zimbabwe}

Zimbabwe ratified the SADC Protocol against Corruption in 2004, the African Union Convention on Preventing and Combating Corruption in 2006, and the UN Convention against Corruption in 2007.

To combat corruption, the Government established in 2004 the Zimbabwe AntiCorruption Commission (ZACC). The ZACC was established in the Zimbabwean Constitution (amended in 2013) ${ }^{59}$ and its responsibilities are further explained in the Anti-Corruption Commission Act (see below). The ZACC is a state-owned enterprise subordinate to the Minister of Home Affairs. The Commission is responsible for investigating and exposing cases of corruption in the public and private sectors. Other bodies relevant to the fight against corruption in Zimbabwe include the Department of Anti-Corruption and AntiMonopolies in the Ministry of Home Affairs, the Attorney General's Office, the National Prosecuting Authority, the Zimbabwe Republic Police, the Financial Intelligence Unit (within

57. See online here: www.saps.gov.za/dpci/index.php

58. See online here: /www.siu.org.za/

59. See online here: www.parlzim.gov.zw/attachments/article/56/constitution.pdf 
the Reserve Bank of Zimbabwe), the National Economic Conduct Inspectorate, and the Public Service Commission. ${ }^{60}$ The legal foundation for Zimbabwe's anti-corruption efforts includes the following legislative acts:

- The Constitution of Zimbabwe established the ZACC in 2005, as well as the National Prosecuting Authority. It also sets forth responsibilities for public officers and civil service conduct.

- The Anti-Corruption Commission Act $(2004)^{61}$ sets forth the scope of responsibilities for the Zimbabwe Anti-Corruption Commission.

- The Criminal Law (Codification and Reform) Act $(2004)^{62}$ establishes bribery and corruption offences, including domestic active and passive bribery (Art. 170) and abuse of functions (Art. 174), as well as embezzlement in the public and private sectors (Art. 113). It also includes SOEs in its definition of a "statutory body".

- The Audit Office Act, along with the Constitution and the Public Finance Management Act, provide the framework for Zimbabwe's supreme audit institution, the Comptroller and Auditor General. ${ }^{63,64}$

- The Procurement Act of $2001^{65}$ established the State Procurement Board, which is responsible for public procurement contracting on behalf of procuring entities, to supervise procurement proceedings, and to investigate possible violations of procurement procedures.

- The Serious Offences (Confiscation of Profits) Act $(1990)^{66}$ provides for the confiscation of money and property used in or in connection with, or as proceeds from, crime.

- The Pubic Finance Management Act (Chapter 22, Art. 19) provides a legal framework for the financial management, corporate governance and auditing requirements for SOEs.

- $\quad$ The Reserve Bank Act (Chapter 22, Art. 15) regulates for the regulation, supervision and conduct of SOEs in the financial sector.

60. United Nations Conference of the States Parties to the UNCAC, Executive Summary of the review of Zimbabwe's Implementation of the UNCAC, CAC/COSP/IRG/1/2/1/Add.17, June 2013 (www.unodc.org/documents/treaties/UNCAC/WorkingGroups/ImplementationReviewGroup/ExecutiveS ummaries/V1384501e.pdf)

61. See online here: track.unodc.org/LegalLibrary/LegalResources/Zimbabwe/Laws/Zimbabwe\%20AntiCorruption\%20Commission\%20Act\%202004.pdf

62. See online here: www.kubatana.net/docs/legisl/criminal law code 050603.pdf

63. See online here: www.auditgen.gov.zw/

64. For more on Zimbabwe's legal framework for auditing public institutions, see: Zinyama, Tawanda, "Efficiency and Effectiveness in Public Sector Auditing: An Evaluation of the Comptroller and Auditor General's Performance in Zimbabwe from 1999 to 2012," International Journal of Humanities and Social Science, Vol. 3 No. 7, April 2013 (www.ijhssnet.com/journals/Vol 3 No 7 April 2013/29.pdf)

65. See online here: www.parlzim.gov.zw/attachments/article/108/PROCUREMENT ACT 22 14.pdf

66. See online here for an unofficial link to the law: www.issafrica.org/cdct/mainpages/pdf/Terrorism/Legislation/Zimbabwe/Zimbabwe\%20Serious\%20offe nces\%20Confiscation\%20of\%20Profits\%20Act\%201990.pdf 
- The Bank Use Promotion and Suppression of Money Laundering Act (Chapter 24, Art. 24) deters money laundering by SOEs, specifically those in the financial sector.

According to Zimbabwe's responses to the stocktaking questionnaire, as well as the publicly available 2013 executive summary of Zimbabwe's implementation of the UNCAC, Zimbabwe's Criminal Law (Art. 277) and Criminal Procedure and Evidence Act (Art. 385) also provide for corporate criminal liability for corruption offences.

\section{SOE-specific measures for combating corruption and promoting business integrity}

\section{$2.1 \quad$ Overview}

This section of the report focuses on the application of anti-corruption frameworks to southern African SOEs and to companies doing business with SOEs. (See Table 5 for the overall size and organisation of SOE sectors in the countries participating in this stocktaking exercise.) Where possible, attention is paid to any special measures governments or SOEs themselves have taken to address the particular corruption risks faced by enterprises of a commercial nature that are partly or wholly owned by the State. The country profiles, below, also include initiatives taken by SOEs themselves to combat corruption and adopt business integrity measures.

As noted above, state-owned enterprises are uniquely exposed to the risk of corruption, due in part to their proximity to government, as well as their tendency to operate in high-risk industries. Examples of corruption in the SOE sector included in stocktaking responses included cases of corruption within SOEs (i.e., bribery solicitation, abuse of office, embezzlement and/or the misappropriation of public funds), as well as corrupt businesses bribing SOEs and their employees for undue business advantages. According to the stocktaking survey responses, corruption negatively impacts SOEs in a number of concrete ways. For example, because of bribery and corruption, projects carried out by or with SOEs are late, incomplete, or substandard. In some cases, corruption has led SOEs to be chronically reliant on government subsidies. Corruption in the SOE sector also leads to market distortions and a loss of public confidence in the use of public assets by SOEs, authorities add.

The anti-corruption laws, rules, and policies described above were implemented to address this risk. Countries participating in the stocktaking survey stated that these frameworks apply to SOEs and their employees in their jurisdictions and that, in all cases, there are no SOE-specific anti-corruption laws. For example, supreme audit institutions have jurisdiction over SOEs in Malawi and Mozambique. Four of the seven countries participating in this exercise reported that SOE employees are considered public officials under their laws, which would impact the application and enforcement of anti-bribery laws in those jurisdictions. SOE employees in Mozambique and South Africa are not considered public officials and therefore are not bound by laws, regulations or codes of ethics for public servants. In Malawi, Mozambique, South Africa, and Zimbabwe, authorities reported that SOEs may be held liable for corruption offences under those countries' corporate liability regimes.

Most of the survey responses indicated that their SOEs are also subject to additional binding and non-binding laws, regulations, and policies on the broader issue of SOE corporate governance. Many of the issues covered by the SOE corporate governance 
framework complement and support efforts to combat corruption in the SOE sector, including for example, the introduction of codes of ethics for public officials (which apply to SOE employees in jurisdictions where they are considered public officials) and requiring SOEs to submit regular financial and performance reports. Efforts to prevent corruption and promote business integrity are further complemented by both public and private sector efforts to promote codes of corporate governance and ethics applicable to both private and stateowned enterprises.

There is a gap, however, between implementing anti-corruption laws and regulations, and enforcing them. While the overall anti-corruption framework in each of the countries participating in the stocktaking has a basic anti-corruption legal framework in place, all of them underlined the difficulty of enforcing this framework, including in the SOE sector. As described more fully below, law enforcement has had difficulty bringing corruption cases involving SOEs to court, either because of a lack of will to prosecute SOEs and their employees, or because of a lack of capacity to properly investigate allegations of corruption and collect sufficient evidence, or, more broadly, there is simply a lack of awareness of the laws and regulations against bribery and corruption and how they should be applied.

This challenge is not unique to southern Africa. For example, only 17 of the 41 States Parties to the OECD Anti-Bribery Convention have sanctioned an individual or company for the crime of foreign bribery since the Convention entered into force in 1999. ${ }^{67}$ Eight countries have received specific recommendations from the Working Group on Bribery in International Business Transactions, which monitors States' Parties' implementation of the Convention, regarding the application of their anti-bribery framework to SOEs. ${ }^{68}$ Based on responses to the stocktaking survey from seven SADC countries, however, it appears that the enforcement gap may be especially wide in terms of holding SOEs accountable for corrupt acts. Specific challenges are further described in the country profiles, below.

Important steps are being taken at the SOE level in Southern Africa, which indicate a growing awareness that bribery and corruption is no longer "part of business as usual". This is particularly evident, experts say, in economies where SOEs make up part of the global supply chain of multinational enterprises subject to anti-corruption legislation with extraterritorial jurisdiction, such as the United States Foreign Corrupt Practices Act or the United Kingdom Bribery Act. Under these laws, companies under the U.S. or U.K. jurisdiction could be held liable for acts of bribery and corruption perpetrated by agents and entities working under their direction, including state-owned enterprises. They can also be prosecuted for bribery if they offer, promise, or give a bribe to an SOE employee for undue advantages, if that employee is considered a public official in the jurisdiction where the bribery took place.

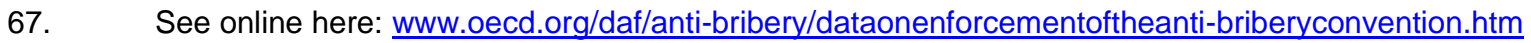

68. These countries include the Czech Republic, Iceland, Mexico, Portugal, South Africa, and Spain. All country reports are available in their entirety on the OECD website here: www.oecd.org/daf/antibribery/countryreportsontheimplementationoftheoecdanti-briberyconvention.htm 
Table 5. Size and organisation of SOE sectors in Botswana, the DRC, Malawi, Mozambique, Seychelles, and Zimbabwe ${ }^{69}$

\begin{tabular}{|c|c|c|c|}
\hline Country & $\begin{array}{l}\text { No. of wholly or } \\
\text { majority-owned } \\
\text { SOEs }\end{array}$ & SOEs' legal status & $\begin{array}{l}\text { Agency exercising or coordinating ownership } \\
\text { function }\end{array}$ \\
\hline Botswana & $\begin{array}{l}49 \\
\text { (19 commercial) }\end{array}$ & $\begin{array}{l}\text { Mixed } \\
\text { (SOEs are a mix of statutory } \\
\text { corporations and firms } \\
\text { incorporated according to the } \\
\text { Companies Act.) }\end{array}$ & $\begin{array}{l}\text { Ownership function exercised by line ministries } \\
\text { and coordinated by the Public Enterprise } \\
\text { Evaluation and Privatisation Agency (PEEPA). } \\
\text { PEEPA is subordinate to Botswana's Ministry of } \\
\text { Finance and Development Planning. }\end{array}$ \\
\hline DRC & 75 & $\begin{array}{l}\text { Mixed } \\
\text { (SOEs include } 20 \text { SOEs and } 55 \\
\text { government-controlled entities, } \\
\text { established under company law } \\
\text { or statutory legislation.) }\end{array}$ & $\begin{array}{l}\text { Comité de pilotage de la réforme des entreprises } \\
\text { du portefeuille de l'état (COPIREP) } \\
\text { COPIREP reports to the Ministry of Portfolio }\end{array}$ \\
\hline Malawi & 50 & $\begin{array}{l}\text { Mixed } \\
\text { (SOEs are established via Acts of } \\
\text { Parliament, Government Orders, } \\
\text { under the Companies Act and via } \\
\text { Trust Deeds.) }\end{array}$ & $\begin{array}{l}\text { Coordinated by Department of Statutory } \\
\text { Corporations. } \\
\text { The Department is subordinate to the President } \\
\text { and Cabinet. }\end{array}$ \\
\hline Mozambique & $35^{2}$ & $\begin{array}{l}\text { Mixed } \\
\text { (SOEs are expected to follow the } \\
\text { Commercial Code, which governs } \\
\text { the establishment, operation, and } \\
\text { governance of enterprises. } 14 \\
\text { SOEs were established under } \\
\text { public enterprise law/specific } \\
\text { legislation.) }\end{array}$ & $\begin{array}{l}\text { Coordinated by the Instituto das Participacoes do } \\
\text { Estado (IGEPE). } \\
\text { IGEPE reports to the Ministry of Finance } \\
\text { (The ownership function is also coordinated by } \\
\text { the National Treasury, which operates under the } \\
\text { Ministry of Finance and the technical tutelage of } \\
\text { related sectorial ministries.) }\end{array}$ \\
\hline Seychelles & $\begin{array}{l}9 \text { SOEs and } 58 \\
\text { other corporate } \\
\text { bodies }\end{array}$ & $\begin{array}{l}\text { Mixed } \\
\text { (SOEs may be established under } \\
\text { the Companies Act, or via SOE } \\
\text { specific legislation/government } \\
\text { orders.) }\end{array}$ & $\begin{array}{l}\text { Coordinated by the Public Enterprise Monitoring } \\
\text { Commission (PEMC). } \\
\text { PEMC reports to the Ministry of Finance. }\end{array}$ \\
\hline South Africa & $\begin{array}{l}300 \text { publicly } \\
\text { owned SOEs ( } 500 \\
\text { if subsidiaries are } \\
\text { included) }\end{array}$ & $\begin{array}{l}\text { Mixed } \\
\text { (SOEs may be incorporated under } \\
\text { the Company Act, or via SOE- } \\
\text { specific legislation.) }\end{array}$ & $\begin{array}{l}\text { The Department of Public Enterprise oversees six } \\
\text { of South Africa's largest SOEs. Ownership of the } \\
\text { remaining SOEs is dispersed across a number of } \\
\text { other line ministries. } \\
\text { DPE reports to the Cabinet. The Treasury plays } \\
\text { an oversight role on budgetary matters. }\end{array}$ \\
\hline Zimbabwe & 78 & $\begin{array}{l}\text { Mostly statutory corporations } \\
\text { (Some SOEs are established } \\
\text { under the Company Act or Acts of } \\
\text { Parliament.) }\end{array}$ & $\begin{array}{l}\text { State Enterprise Restructuring Agency (SERA) } \\
\text { SERA serves as the technical arm to the } \\
\text { Ministry of Finance and Economic Development } \\
\text { and the Cabinet Committee on Parastatal } \\
\text { Development (CCPD. }\end{array}$ \\
\hline
\end{tabular}

3. According to government plans published in April 2014, an agency called the Corporate Governance Delivery Agency will be established under the Office of the President as a means to more centrally coordinate SOE.

Source: Sultan Balbuena, S. (2014), "State-Owned Enterprises in Southern Africa: A Stocktaking of Reforms and Challenges", OECD Corporate Governance Working Papers, No. 13, OECD Publishing

69. The number of wholly or majority owned SOEs and respective governance arrangements reflected in Table 5 are current as of end-2014. 
Measures implemented by SOEs to protect their business operations from the risk of corruption include developing codes of corporate governance for SOEs with specific anticorruption provisions or encouraging SOEs to adopt anti-corruption codes of conducted developed for the private sector but with applicability to SOEs, as seen in Botswana, Malawi, and Mozambique. In some cases, these codes are developed in collaboration with law enforcement and anti-corruption bodies. SOEs, such as those in Malawi, are also developing internal codes of conduct and anti-corruption policies, for example. These examples, and more, are included in more detail in the country profiles provided below.

\section{Box 2. Highlights: SOE-led anti-corruption and business integrity initiatives in Southern Africa}

Addressing the issue of anti-corruption, ethics and responsible business conduct in the SOE sector is multidimensional. It includes governments having the right laws and rules in place and ensuring they are effectively enforced. This effort also necessarily includes ensuring good governance practices at the level of the SOEs-themselves. For example, these efforts could include (but are not limited to):

- Holding stakeholder consultations to identify corruption risks and opportunities;

- Including independent directors on boards of directors;

- Introducing relevant committees to deal with corruption-related issues, including ethics and audit committees;

- Implementing company-specific codes and policies on company ethics consistent with national anticorruption frameworks;

- $\quad$ Ensuring hiring, public procurement, and privatisation practices are open and competitive; and

- $\quad$ Providing clear channels for reporting misconduct and effective whistle blower protections.

Below are examples of SOE-specific anti-corruption and business integrity initiatives taken by governments and SOEs in some of the countries participating in this stocktaking survey.

\section{Botswana}

- The 2012 Guidelines for Shareholder Oversight over Parastatals provide line ministries advice on defining state ownership objectives, drawing up "shareholder compacts" between the state shareholder and the SOE board chair and board charters, undertaking board evaluations, and implementing internal control systems.

- Some SOE boards have voluntarily included issues of ethics and codes of practice in their board charters, including whistleblowing policies.

- SOEs are encouraged to apply the Code of Conduct for the Private Sector, developed by the Botswana Chamber of Commerce and Industry, in collaboration with Botswana's anti-corruption authority.

Malawi

- All SOEs are required to have: anti-corruption policies and risk management guidelines that address corruption issues, as well as internal audit functions. Some of these policies were developed with the assistance of Malawi's Anti-Corruption Bureau.

- $\quad$ SOEs are encouraged to apply the Sector Guidelines for Parastatal Organisations and State-Owned Enterprises, which adapts Malawi's National Code of Governance to SOEs, as well as the Malawi Business Code of Conduct for Combating Corruption (BCCC), developed by the Malawi Business Action against Corruption Taskforce. 
Mozambique

- $\quad$ SOEs are encouraged to apply the Government's Guide on Corporate Governance Best Practices in State Shareholding Enterprises and to reference the private sector's Toolkit on Combating Business Participation in Corruption in Mozambique.

- A number of SOEs have established committees and management units that are responsible for monitoring the implementation of internal codes of ethics.

- $\quad$ One SOE invited Mozambique's anti-corruption authority to lecture managers on the content and scope of Mozambique's anti-corruption framework.

Seychelles

- Since 2013, SOEs must submit performance audited financial reports to the body coordinating the state enterprise ownership function. The board of each SOE must also submit a statement of corporate intent, updated regularly.

- Several SOEs in the Seychelles have also adopted codes of conduct.

South Africa

- The Department of Public Enterprises (DPE), which oversees six of South Africa's largest SOEs, introduced three years ago a data analytics system to monitor SOE performance on a continual basis, complementing existing disclosure requirements under laws applicable to private and public entities.

- The electricity utility Eskom, for example, views its reporting and disclosure obligations as "an opportunity to deal with information management in a holistic and integrated manner". Doing so, helps to ensure investors that investing in Eskom "is a good investment and a trusted, ethical, and wellgoverned company, highly rated by all its stakeholders".

\section{Zimbabwe}

- $\quad$ The Government is currently codifying the SOE corporate governance framework.

- Some SOEs have developed procedural manuals in order to regulate the conduct of business transactions.

\section{$2.2 \quad$ Country profiles}

\subsubsection{Botswana}

In Botswana, law enforcement authorities have carried out several investigations involving corruption within SOEs, though only a few cases have been brought to court, due to the lack of prosecutable evidence, authorities reported. In one recent case, for example, a former SOE senior manager was accused of accepting bribes in relation to the award of tenders for a series of construction projects. The case was suspended after the accused manager fled the country.

These investigations were carried out under Botswana's anti-corruption framework, described above. The corruption offences set forth in the Corruption and Economic Crime Act, the Penal Code, and other laws apply to SOEs and their employees. The DCEC's jurisdiction includes the ability to investigate allegations of corruption involving SOEs and their employees, which are considered public officials under Art. 2 of the Corruption and Economic Crime Act. To address the specific risks faced by SOEs and other public bodies, the DCEC's Corruption Prevention Department conducts operational audits central and local 
government bodies, as well as SOEs, to assess their exposure to the risk of corruption and to raise greater awareness in the public sector of these risks. ${ }^{70}$ In addition, Botswana's Parliament has instituted a number of commissions of enquiry against several SOEs to investigate corruption allegations, including allegations involving the Botswana Development Corporation, the Botswana Housing Corporation, and the Botswana Meat Commission.

Botswana's SOEs and their employees are subject to additional rules to improve their corporate governance. These rules complement the framework in place for preventing corruption in the SOE sector. They include the Privatisation Policy of $2000^{71}$ and the 2012 Guidelines for Shareholder Oversight over Parastatals, which provide corporate governance advice to line ministries exercising the state enterprise ownership function. ${ }^{72}$ The Privatisation Policy established the state-owned enterprise, the Public Enterprise Evaluation and Privatisation Agency (PEEPA). PEEPA, which reports to the Ministry of Finance and Privatisation Planning, plays a coordinating role in terms of overseeing the performance and governance of SOEs in Botswana. It is also responsible for overseeing implementation of the 2012 Shareholder Guidelines, though PEEPA has no legal authority over SOEs.

Botswana's authorities reported that the Government is considering an overarching state enterprise ownership policy, which will include provisions relating to the mismanagement of resources. Consideration may also be given to developing a corporate governance code for SOEs and companies in Botswana. The lack of corporate governance guidance "leaves too much room for discretion," Botswana's authorities report, especially given the country's decentralised ownership system.

According to Botswana's stocktaking survey responses, the boards of many SOEs have included issues of ethics and codes of practice in their board charters. A number have also implemented whistleblowing policies, even though, as mentioned above, the Government has not yet enacted whistle blower protection legislation.

More broadly, anti-corruption initiatives carried out in the private sector could serve as useful guidance for SOEs, Botswana's survey responses noted. For instance, the DCEC, in collaboration with the Botswana Chamber of Commerce and Industry, has developed a Code of Conduct for the Private Sector. ${ }^{73}$ The Code represents commitments voluntarily made by companies, associations, and other entities to address concerns over the standards of conduct and integrity in the private sector. It aims to guide directors, managers, and employees through situations where they and/or their companies may be exposed to the risk of corruption. Promotion of the Code's implementation will be carried out by the newly formed association, Business Action against Corruption.

70. See online here: www.gov.bw/en/Ministries--Authorities/Ministries/State-President/Department-ofCorruption-and-Economic-Crime-DCEC/Divisions/Corruption-Prevention/

71. See online here: www.peepa.co.bw/sites/default/files/Privatisation\%20Policy\%20of\%20Botswana.pdf

72. See online here: www.peepa.co.bw/sites/default/files/GUIDELINES\%20TO\%20IMPROVE\%20SHAREHOLDER\%200V ERSIGHT\%200VER\%20PARASTATALS\%202.pdf

73. See online here: www.boccim.co.bw/images/code of conduct-Final.pdf 


\subsubsection{Democratic Republic of Congo}

While the DRC's anti-corruption framework applies equally to SOEs and their employees, authorities report that efforts to enforce laws and regulations against SOEs has been difficult, despite efforts by Parliament, the Court of Auditors, finance inspect, the state auditor, and the judiciary. This has a significant negative impact on the DRC's economy and level of governance, given that Congolese SOEs account for approximately 80 percent of the national economy, and most of them operate in a monopoly situation. SOEs are among the country's largest companies, including the Générale des Carrières et des Mines (GECAMINES), the Société Nationale d'électricité (SNEL) and the Société Nationale des Chemins de fer du Congo (SNCC). Government authorities report that all of these enterprises are performing poorly, are under-productive, provide only mediocre goods and services, and are overstaffed.

There have been a large number of corruption allegations involving SOEs that have never been brought to court, due to low enforcement of the DRC's anti-corruption framework. These cases illustrate, authorities say, how corruption has negatively impacted the DRC's SOE sector. The corruption is facilitated by, for example: a lack of transparency in recruitment and human resources management; bribery and the lack of competition in the award of public procurement contracts; and embezzlement, misuse and misappropriation of SOE funds and resources, including natural resources.

Fighting corruption and improving SOE corporate governance, however, remain government priorities. Corporate governance reforms began in 2003 as part of a wider effort to liberalize and open up to competition a number of key sectors, including energy, mining, transport, telecommunications and financial services. Broadly, these reforms-undertaken with the support of the World Bank-are meant to bring SOEs and how they are managed closer in line with DRC's commercial law and private sector best practices. They also included rules and regulations for privatising non-strategic State assets in a transparent manner. To implement these reforms, the Government established the Comité de pilotage de la réforme des entreprises du portefeuille de l'état (COPIREP). COPIREP's duties include working on the implementation of SOE-specific corporate governance plans. These plans include working with SOEs to require SOE boards to establish ethics, audit, and good governance committees, as well as to introduce whistle blower systems to report potential misconduct, including alleged fraud and corruption.

Resources are available to SOEs in the DR Congo to further strengthen their corporate governance frameworks, including methods for preventing corruption and promoting business integrity. For example, the Government issued in February 2013 additional good governance guidance for SOEs operating under Company Law, the "Règles de Bonne Gouvernance Relatives aux Entreprises Publiques Transformée en Sociétés Commerciales". ${ }^{74}$ A multi-stakeholder private sector group representing the Fédération des Entreprises du Congo, the Ethics Institute of South Africa, the African Institute of Corporate Citizenship (AICC), Business Action against Corruption (BAAC), and the United States Institute of Peace (USIP) also developed in 2010 a Business Code of Conduct for the Private Sector in the DRC. ${ }^{75}$ The Code states specifically that it can be applied to state-owned enterprises. A number of Congolese SOEs have also volunteered to implement measures to

\footnotetext{
74. Sultan Balbuena, p. 27.

75. See online here: www.baacafrica.org/w/ops drc.php
} 
combat corruption and promote business integrity, including the adoption of corporate governance codes, codes of ethics, and whistle blower systems.

Before these efforts can have their intended positive effect, government authorities state that more must be done to actively apply the existing anti-corruption and corporate governance framework in the DRC. This requires having the political will to hold SOEs accountable and to sanction SOEs for corrupt behaviour. The DRC's stocktaking response also suggests that the Government should also do more to raise greater anti-corruption awareness among all SOE stakeholders, including shareholders, officers, employees, unions, customers, suppliers, etc.; and strengthening whistle blower systems and protections.

\subsubsection{Malawi}

In Malawi, the so-called "cash-gate" corruption scandal has dominated headlines since autumn 2013, when news broke that up to USD 250 million had been stolen from public coffers by manipulating a government software system to make fraudulent payments to external providers for goods and services that were never rendered. ${ }^{76}$ The scandal led to a temporary suspension of foreign aid, which makes up approximately $40 \%$ of Malawi's budget. Allegations have pointed to possible SOE involvement in the scheme.

Malawi's National Integrity System was designed to tackle problems like this one, and its focus includes ensuring that SOEs conduct their business cleanly and responsibly. The AntiCorruption Bureau is empowered under the Corrupt Practices Act, to investigate corruption crimes involving any person or institution, public or private. The Office of the Director of Public Procurement is also authorized to commence legal proceedings against any person or institution suspected of engaging in corrupt practices in procurement. Further, the Auditor General, under the Public Audit Act, has jurisdiction over corporations where the Government directly or indirectly: controls the composition of any board of directors of the body, controls more than $50 \%$ of the voting power of the body, or holds more than $50 \%$ of any of the issued share capital of the body either directly or through another agency or statutory body (Art. 2). Finally, SOEs can be held liable under Malawi's corporate liability regime. SOE employees in Malawi are considered public servants under the Corrupt Practices Act and are subject to the Public Service $\mathrm{Act}^{77}$ and the Public Service Regulations ${ }^{78}$.

76. See, for example, the report prepared by Baker Tilly Business Services Limited at the request of the UK Department for International Development for the Government of Malawi: Baker Tilly (2014), National Audit Office Malawi: Report on Fraud and Mismanagement of Malawi Government Finances, Covering Transactions and Controls in the Six Month Period 1 April 2013 - 30 September 2013, 21 February 2014 (www.gov.uk/government/uploads/system/uploads/attachment data/file/285877/20140221 National A udit Office Malawi - Forensic Audit Report - FINAL ISSUED.pdf). See also, "Malawi's "cashgate" scandal: The $\$ 32 \mathrm{~m}$ heist", Economist, 27 February 2014 (www.economist.com/blogs/baobab/2014/02/malawi-s-cashgate-scandal)

77. See online here: track.unodc.org/LegalLibrary/LegalResources/Malawi/Laws/Public\%20Service\%20Act\%20(1994).pdf

78. See online here: www.issafrica.org/cdct/mainpages/pdf/Corruption/Legislation/Malawi/Malawi\%20Public\%20Service\%20 Regulation.pdf 
Malawi's stocktaking survey responses report that the Government has taken some extra steps to prevent corruption in the SOE sector, specifically. These include requiring all SOEs to have anti-corruption policies and implementation strategies and guidelines. In addition, SOE risk management guidelines should contain guidelines on corruption issues. All SOEs must also have functioning internal audit functions, authorities report.

In addition to the laws and rules making up Malawi's National Integrity System is the framework designed to ensure SOE corporate governance. SOEs in the country are overseen by the Department of Statutory Corporations, which is subordinate to the Office of the President and Cabinet. The Department is charged with oversight of SOEs' operations and financial performance, in cooperation with line ministries. It is also tasked with ensuring SOEs incorporate issues of business integrity in their management plans and budgets in compliance with the National Integrity System requirements. Finally, the Ministry of Finance, which also holds state shares in a number of SOEs, also has a unit that monitors the performance of large SOEs.

SOEs in Malawi are encouraged to apply the Sector Guidelines for Parastatal Organisations and State-Owned Enterprises, which was developed by the Malawian Institute of Directors in 2011. ${ }^{79}$ The Guide clarifies how Malawi's National Code of Governance applies to SOEs. The Guide states that adoption of the Code's corporate governance practices by SOEs will lead to: "sustainable businesses, improved transparency, increased trustworthiness, less corruption, economic development and poverty reduction." Regarding anti-corruption, specifically, Chapter 4 of the Code, which explains the role of the board, states that the board should decide on strategic corporate planning...comprising (at least)... key issues on risk management and fraud and corruption prevention."

In addition, SOEs are encouraged to apply the Malawi Business Code of Conduct for Combating Corruption (BCCC), ${ }^{80}$ which was developed by a multi-sector steering committee of the Malawi Business Action against Corruption Taskforce. The BCCC's aim is to provide a framework of good business practice for all businesses, public or private, small or large, by eliminating corrupt practices and making a positive contribution to improving business standards. Provisions cover bribery, extortion, abuse of position of authority, influence peddling, embezzlement and fraud.

Finally, a number of SOEs in Malawi have developed internal corruption-prevention policies, with the assistance of Malawi's Anti-Corruption Bureau. These SOEs include: the Malawi Revenue Authority, the Electricity Supply Corporation of Malawi, the Northern Region Water Board, the Southern Region Water Board, the Malawi Posts Corporation, the Central Region Water Board, and the Tobacco Control Commission. Many SOEs in Malawi are also members of local professional and business associations, such as the Chamber of Commerce and the Confederation of Industry and Services.

\subsubsection{Mozambique}

Government authorities in Mozambique report that there has been progress in the fight against corruption. What used to be considered as "business as usual" is now recognized as

79. See online here: www.ecgi.org/codes/documents/sector guidelines parastatal soe malawi 3feb2011 en.pdf

80. Available online here: www.track.unodc.org/LegalLibrary/pages/LegalResources.aspx?country=Malawi 
corruption, even though this remains difficult for some to accept. There have also been at least two documented court cases, which are ongoing and which involve an SOE: The GCCC's 2012 annual report indicated that two senior managers of a Maputo-based SOE who had allegedly stolen money from the SOE and had been charged with abuse of office and abuse of trust.

Mozambique's anti-corruption framework, outlined above, also applies to SOEs, and SOEs as legal entities can be held liable for corruption offences under Mozambican law. SOE employees in are not considered public officials.

While there are no specific anti-corruption measures in Mozambique for SOEs, the SOE corporate governance framework includes elements that strengthen efforts to prevent corruption in the sector. First, wholly-owned SOEs (most often operating in public utility sectors) are also regulated by the Law of Public Enterprises (Law 6/2012 of 8 February). ${ }^{81}$ In adopting this law, the Government aimed to enhance its monitoring of the activities of public enterprises in order to reduce fiscal risk, improve governance, and strengthening accountability. Examples of wholly state-owned companies subject to the Law of Public Enterprises include Electricidade de Moçambique (EDM), Caminhos de Ferro da Colónia de Moçambique (CFM), and Empresa Nacional de Hidrocarbonetos (ENH). In 2013, the IMF positively viewed adoption of the Law of Public Enterprises as a step forward in Mozambique's efforts to improve good governance and to fight corruption in the SOE sector. $^{82}$ (Commercially oriented state-owned or state-controlled companies are regulated by the Commercial Code. ${ }^{83}$ )

In addition, Mozambican authorities reported that they are considering a draft Law on the Corporate Sector of the State. The draft law is in its final stages of preparation. It will require SOEs to disclose and quantify in their financial statements: (i) all direct and indirect support, including transfers, between the Government and public enterprises on an annual basis, and (ii) the cost of any provision of goods or services at below-market prices and any other quasi-fiscal activities. ${ }^{84}$ In combination with the Public Probity Law (Law Nr. 16/2012), the new law would also require the publication of an annual report on the overall financial performance of SOEs in Mozambique. It would also require the Instituto de Gestao das Participacoes do Estado ("Institute for the Management of State Holdings, or IGEPE), which exercises the state ownership function in coordination with the Ministry of Finance, to prepare an annual report on the implementation of the principles of best practices in corporate governance in all companies with State participation. In 2013, IGEPE also rolled

81. Law 6/2012 of 8 February is operationalised by the Decree No.84/2013 of 31 December.

82. IMF (2013), Republic of Mozambique: Staff Report for the 2013 Article IV Consultation, Sixth Review under the Policy Support Instrument, Request for a Three-Year Policy Support Instrument, and Cancellation of Current Policy Support Instrument, IMF Country Report No. 13/200, p. 51 (www.imf.org/external/pubs/ft/scr/2013/cr13200.pdf)

83. Cohen, Elin, Thomas Selemane and Mariam Umarji (2014), The State's Engagement in Business in Mozambique ,Mozambique Support Programme for Economic and Enterprise Development (SPEED), USAID/Mozambique, August 2014 (www.speed-program.com/wp-content/uploads/2014/08/2014SPEED-Report-011-The-states-engagement-in-Business-EN.pdf), p. 26.

84. IMF (2014), Republic of Mozambique: Letter of Intent, Memorandum of Economic and Financial Policies, and Technical Memorandum of Understanding, April 23, 2014 (www.imf.org/External/NP/LOI/2014/MOZ/042314.pdf) 
out a new computerized monitoring system for financially monitoring companies in which the State holds shares. ${ }^{85}$

SOEs are also subject to audits by the General Inspection of Finance, Mozambique's supreme audit institution), and their financial performance is also monitored by the National Directorate of the Treasury. Both bodies, as well as IGEPE, report to the Ministry of Finance, and all of them are expected to play a role in monitoring the implementation of Mozambique's anti-corruption laws and rules by SOEs.

In 2009, IGEPE also developed a voluntary Guide on Corporate Governance Best Practices in State Shareholding Enterprises. It is also developing a series of new management tools to improve mechanisms to improve SOE corporate governance and SOE management performance. These include introducing software to monitor company performance, called the Integrated System for the Monitoring and Supervision of Participations (SIMAP); management contracts with fixed performance targets; and a corporate governance manual for SOEs.

At the SOE level, Mozambican authorities report that a number of SOEs have established committees that are responsible for monitoring the implementation of internal codes of ethics. There have been cases where SOEs have applied punitive measures when internal ethics provisions were violated, in order to discourage employees from entering into corrupt practices, authorities add.

Examples of SOEs implementing anti-corruption measures include national insurance agency Empresa Moçambicana de Seguros (EMOSE), which has adopted a code of conduct and ethics that is mandatory for managers and workers. EMOSE has also invited GCCC to give a lecture to managers on the content and scope of Mozambique's anti-corruption framework. The company has also established Investment and Human Resources Committees. At Telecomunicações de Moçambique (TDM), the company has created a Revenue Assurance and Fraud Unit, whose responsibilities include: monitoring and analysing operations reports, in order to identify problems related to revenue assurance; researching the causes of fraud and its consequences; suggesting mechanisms for eliminating fraud; providing referrals of allegations of possible unlawful or illegal activities; and assessing ways to retrieve company assets that may have been fraudulently obtained by employees or external agents.

SOEs in Mozambique also have for reference the 2006 Toolkit on Combating Business Participation in Corruption in Mozambique, ${ }^{86}$ published by the Sofala Commercial and Industrial Association (ACIS), in partnership with Washington-based Centre for International Private Enterprise (CIPE). The toolkit summarizes Mozambique's anti-corruption laws, regulations, and policies, and provides sample codes of ethics and business principles, as well as training materials.

Looking forward, Mozambique's responses include ways to further combat corruption and promote SOE business integrity. These include: carefully selecting public managers according to their skills and proven integrity; promoting internal and external inspections and

85. "Mozambique: Igepe Introduces New Management Model," AllAfrica.com, 22 August 2013 (http://allafrica.com/stories/201308221301.html)

86. See online here: www.acismoz.com/lib/Programmes/Business-against-corruption/ACIS\%20anticorruption\%20toolkit.pdf 
audits; creating and disseminating codes of conduct and ethics that are binding; and training managers in matters of good corporate governance and anti-corruption.

\subsubsection{Seychelles}

The Seychellois authorities report that, in their jurisdiction, the perceived corruption risks in the SOE sector include embezzlement, collusion, and the misappropriation of State funds. If left unchecked corruption in the SOE sector can facilitate further fraud and theft of public funds, can distort markets, and can result in the inability to deliver needed public goods and services.

While there is no SOE-specific anti-corruption policy in the Seychelles, SOEs are subject to Seychelles' laws against corruption and related offences, as described more fully above. And, as in other countries highlighted in this report, the SOE corporate governance framework supports efforts to prevent corruption and to promote business integrity in the SOE sector. For example, the National Assembly's Public Finance Accounts Committee reviews SOEs' accounts and how they manage their financial affairs. The Committee annually reviews all SOE annual reports, which are submitted to Parliament by the Minister of Finance. And, in 2013, the Government created a Public Enterprise Monitoring Commission (PEMC) ${ }^{87}$ in order to ensure SOEs are properly controlled and managed for the purposes of better performance, transparency, and accountability. The PEMC is currently developing non-binding good governance guidelines for SOEs.

The creation of the PEMC and improving SOE governance are part of a broader package of public service reforms introduced by the Government in Seychelles. ${ }^{88}$ As part of these reforms, SOEs must now submit performance audited financial reports to the PEMC. The board of each SOE must also submit to the PEMC a statement of corporate intent, to be updated every three years. The reforms have already translated into improved fiscal performance at the Public Utilities Corporation, according to a 2014 assessment of the Seychellois Government's national development strategy and programme of reform. ${ }^{89}$

Several SOEs in the Seychelles have also adopted codes of conduct, including Air Seychelles, NuovoBanq, and Petro Seychelles. The Seychelles Pension Fund (SPF) has a committee in place to take measures against corruption, authorities stated in the stocktaking survey responses. SPF also has its own code of ethics, which forms an integral part of the terms and conditions of SPF employment. Failure to comply with the code may result in disciplinary action.

87. The PEMC was created under the Public Enterprise Monitoring Commission (PEMC) Act 2013. See online here: www.seylii.org/sc/legislation/act/2013/3

88. World Bank (2014), International Bank for Reconstruction and Development Program Document on a Proposed Loan in the Amount of US\$7.0 Million to the Republic of Seychelles for the Third Sustainability and Competitiveness Development Policy Loan, Report No. 83120-SC, August 29, 2014 (www-wds.worldbank.org/external/default/WDSContentServer/WDSP/IB/2014/09/ 11/000350881 20140911085245/Rendered/PDF/831200PGD0P1460C0disclosed090110140.pdf)

89. World Bank (2014), International Bank for Reconstruction and Development Program Document on a Proposed Loan in the Amount of US\$7.0 Million to the Republic of Seychelles for the Third Sustainability and Competitiveness Development Policy Loan, Report No. 83120-SC, August 29, 2014 (www-wds.worldbank.org/external/default/WDSContentServer/WDSP/IB/2014/09/ 11/000350881 20140911085245/Rendered/PDF/831200PGD0P1460C0disclosed090110140.pdf) 


\subsubsection{South Africa}

South African authorities state that the Government faces numerous challenges when it comes to promoting business integrity in the SOE sector, including unethical individuals, corruption and bribery. For example, the 2014 review of South Africa's implementation of the OECD Anti-Bribery Convention identifies two investigations of alleged foreign bribery involving SOEs in the oil and defence sectors. ${ }^{90}$ Authorities warn that the failure to address these challenges "will result in serious economic consequences with grave socio-economic implications of job losses, loss of revenue by Inland Revenue, erosion of pension reserves, and loss of investor confidence."

South African SOEs and their employees (who are not considered public officials) are subject to South Africa's laws against corruption and related offences, as described more fully above. As semi-public institutions, SOEs are also subject to Treasury regulations and the Public Audit Act, the Promotion of Access to Information Act, and, as mentioned above, the Public Finance Management Act. ${ }^{91}$ The latter provides the financial framework that gives managerial and operational autonomy to SOEs.

South Africa's SOEs are also subject to the broader framework regulating business in, and from, South Africa. This framework includes, but is not limited to, South Africa's Constitution, the Companies Act 2008, which requires the boards of all entities under its jurisdiction to establish Social and Ethics Committees. These Committees are required to include in their terms of reference responsibility for monitoring activities related to: impact on social and economic development, compliance with the United Nations Global Compact Principles, ${ }^{92}$ OECD recommendations regarding corruption, and ensuring compliance with South African labour, employment, and environmental legal requirements, among other measures. SOEs are also subject to the Competition Act, under which the Competition Commission investigates possible anti-competitive trade practices by South African companies, including SOEs. The SOE sector is also subject to sector-specific legislation and policies (e.g., the Electricity Act or the Electronic Communications Act).

The anti-corruption framework is further complemented by South Africa's SOE-specific corporate governance framework, which derives from the 2002 Protocol on Corporate Governance in the Public Sector. ${ }^{93}$ The Protocol governs how SOEs are directed, managed, and held accountable. It is based on the King II Report on Corporate Governance, which is mandatory for companies listed in South Africa. Since its establishment, the Protocol has been updated to reflect developments in South African company law, such as the entry into force of the 2008 Companies Act and corporate governance changes included in the King III report. It obliges SOEs to combat corruption through such mechanisms as risk management

90. OECD (2014), Phase 3 Report on Implementing the OECD Anti-Bribery Convention in South Africa, OECD Publishing. See p. 11.

91. As noted in State-owned Enterprises in Southern Africa: A Stocktaking of Reforms and Challenges, not all provisions of the Public Finance Management Act apply to all SOEs, as different types of entities with various commercial or non-commercial objectives are categorized according to "Schedules" under the Act (p. 41).

92. See online here: www.unglobalcompact.org. Companies that sign up to the Compact commit to aligning their operations and strategies with 10 principles in the areas of human rights, labour, environment, and anti-corruption.

93. See online here: $\underline{w w w . g o v . z a / s i t e s / w w w . g o v . z a / f i l e s / c o r p g o v ~} 0 . p d f$ 
and fraud prevention plans, to disclose material losses as a result of fraud and theft, and to implement a code of ethics for board members and staff.

The SOE corporate governance framework in South Africa also reflects recent and ongoing efforts to reform and restructure public entities, as outlined in the Governance in Restructuring Processes Policy. ${ }^{94}$ The Policy sets forth minimum requirements, including conflict of interest declarations, confidentiality requirements, as well as the requirement that transactions are monitored by an independent auditor. It builds on an earlier effort in 1999 to restructure the SOE sector under the so-called Accelerated Agenda toward the Restructuring of the State-Owned Enterprises, which was meant to "restrict and contain the excesses of SOEs, as well as ensuring business integrity within SOEs." South African authorities report that this effort is ongoing: The Government has commissioned a study into the structure and governance arrangements of public entities.

Eight of South Africa's largest SOEs are overseen by the Department of Public Enterprises (DPE): Eskom, Alexkor, Denel, Safcol, South African Airways, Transnet, Broadband Infraco, and South African Express Airways). The DPE is the only Government Department with the sole mandate of oversight of the SOEs accorded to it. In this capacity, DPE is responsible for ensuring SOEs drive investment, productivity, and transformation in the sectors within which they operate - while also contributing to the broader government development strategy

The DPE reports that, for the last three years, it has employed data analytics to monitor SOE performance (the Isibuko Dashboard). The tool requires SOEs to report on financial performance, job creation and skills development, risk management, and progress on capital expenditure projects and it allows the DPE to review SOE's performance quarterly in accordance with Treasury Regulations and annually in accordance with the Public Finance Management Act and the Companies Act. This information is also used by the Minister of Public Enterprises to issue investor briefs to SOE boards on emerging SOE performance trends, risks, and corrective measures that should be taken to meet key performance indicators.

To address the problem of corruption in the SOE sector and to promote business integrity, the DPE has developed guidelines, codes and legislation on good corporate governance and ethics, such as the Government Shareholder Management and Guidelines on Remuneration Standards and Incentives. SOEs in the DPE portfolio are also required to report to the Department on a quarterly and annual basis on irregular or wasteful expenditures according to a publicly disclosed materiality threshold agreed upon between the Boards and the DPE. The South African authorities add that SOEs must also disclose these incidents to the Executive Authority, the National Treasury, and the Auditor General for the financial year under review. ${ }^{95}$

94. This Policy, and its development, is explained in further detail on page 40 of, State-owned enterprises in Southern Africa: A Stocktaking of Reforms and Challenges.

95. For these reports, the DPE has created a template that requires SOEs to provide information on losses incurred by individual employees, their supervisor(s), the monetary value, the action taken in terms of disciplinary steps, as well as criminal procedures and whether the losses were recovered. South African authorities have volunteered to share this template with the SOE Network for Southern Africa in the furtherance of its work stream on combatting corruption and promoting business integrity in the SOE sector. 


\subsubsection{Zimbabwe}

In Zimbabwe, the Zimbabwean Anti-Corruption Commission (ZACC) has jurisdiction over SOEs and their employees, and is able to carry out SOE audits and reviews. Along with the ZACC, line ministries are responsible for monitoring SOEs' operations and performance and for cooperating with law enforcement, including the ZACC in cases of suspected corruption. These responsibilities were further underlined in 2013 with the adoption of the country's new Constitution, which states that all state-controlled enterprises in Zimbabwe must "conduct their operations so as to maintain commercial viability and abide by generally accepted standards of good corporate governance." They must also "establish transparent, open, and competitive procurement systems" (Art. 195). ${ }^{96}$

Zimbabwe's stocktaking survey responses report, however, that there remains a lack of awareness of the country's anti-corruption laws and how they apply to SOEs, their employees, and those doing business with SOEs. The country continues to face a myriad of challenges in the promotion of business integrity in the SOE sector, particularly in the area of public procurement. Several cases are ongoing, Zimbabwean authorities' report, which involve the misappropriation of State funds, fraud in SOEs, and the abuse of office by SOE officials.

Looking ahead, the Government is considering a number of additional measures to combat corruption and to promote business integrity in the SOE sector. The Government is in the process of establishing a Corporate Governance Delivery Agency under the Office of the President and Cabinet which will promote good corporate governance practices in SOEs. Furthermore, the Government is considering establishing an SOE corporate governance code. Other possible measures could include developing workshops and trainings with representatives from the SOE sector; establishing within SOEs formally recognized AntiCorruption or Integrity Committees to monitor day-to-day operations; researching and adopting best practices in terms of procurement, employment, and investment; and adopting whistle blower protection legislation.

In the meantime, a number of Zimbabwean SOEs have developed procedural manuals in order to regulate the conduct of business transactions. These manuals may include provisions on procurement and advice on ethics and compliance. Some have also established departments to fight corruption in-house.

96. See online here: www.parlzim.gov.zw/attachments/article/56/constitution.pdf 


\section{CONCLUSIONS AND NEXT STEPS}

Some Southern African economies are among the fastest-growing in the world. Yet, perceived levels of corruption remain high, threatening to discourage much-needed foreign and domestic investment and to impede sustainable economic development. Given the role SOEs play in SADC countries as vehicles for development-both in terms of their economic significance and in terms of the responsibility governments have given them to set their country's "business tone"- preventing and shielding SOEs from corruption is of utmost importance to meeting stated development goals.

Members of the SOE Network for Southern Africa have agreed to consider ways in which their governments can combat corruption and promote business integrity in the SOE sector. This stocktaking report highlights efforts made by seven Network members in this regard: Botswana, the DR Congo, Malawi, Mozambique, Seychelles, South Africa, and Zimbabwe. The stocktaking responses indicate that, in the seven participating jurisdictions, governments have worked to fulfil their obligations under international and regional anticorruption instruments to which they are Party. This includes establishing in domestic legislation specific corruption offences and related provisions to facilitate law enforcement agencies' ability to detect, investigate, prosecute, and punish corruption crimes. Authorities report that the anti-corruption frameworks in these countries should apply to enterprises that are controlled or wholly owned by the State, as well as employees of these enterprises.

Corruption, however, remains a challenge to the effective functioning of SOEs. The problem is less a matter of having the right laws in place. Rather, this report indicates that the problem lies both with governments' having the political will, capacity, and resources to apply the law, as well as with SOEs' willingness and ability to address their exposure to corruption by implementing appropriate internal controls, ethics, and compliance measures. As demonstrated, although a number of international and regional commitments exist aimed at combatting corruption and promoting ethical and responsible business conduct, there is still room for improvement.

Fortunately, policy-makers, governments, SOEs, private companies, and civil society largely recognise that corruption should no longer be "part of business as usual". Some of the national experiences highlighted above provide useful examples of practical steps that could be employed for fighting corruption and promoting business integrity in SOEs. These practices could contribute to the SOE Network for Southern Africa's reflection process and could serve as input to more ambitious undertakings by the Network in its future work. 


\section{ANNEX 1. \\ QUESTIONNAIRE: STOCKTAKING OF ANTI-CORRUPTION AND BUSINESS INTEGRITY MEASURES FOR SOUTHERN AFRICAN SOES}

\section{Background}

Corruption undermines good governance, sustainable economic development, and functioning markets. SOEs are uniquely exposed to the risk of corruption, due to their proximity to government and official policymakers. Many SOEs also operate in high-risk industries, such as utilities, oil and gas, power generation and transmission, transportation, telecommunications, and banking and finance. ${ }^{97}$ Corruption risks may include the bribery of SOEs employees by private companies and their employees to obtain unfair business advantages. Or, SOEs and their employees may feel pressured to bribe or take advantage of their unique position in the market to win unfair advantages. In some jurisdictions, SOEs are held responsible for the corrupt acts of their employees.

Given the important role that SOEs play in many countries, clean and efficient SOEs are important to good governance and a well-functioning economy. For this reason, the SOE Network for Southern Africa agreed at their fourth meeting in November 2013 in Swakopmund, Namibia, to look more closely how to combat corruption and promote business integrity in the SOE sector in the Southern African Development Community (SADC).

\section{Purpose}

This questionnaire was developed by the OECD Secretariat on behalf of the SOE Network for Southern Africa, which agreed in Swakopmund to carry out a stocktaking of anticorruption and business integrity measures applying to SOEs in the region. The stocktaking would also recognise corporate governance measures that also increase transparency and help curb corruption, but should focus on measures specifically targeting corrupt behaviour. The stocktaking results could inform the development of an anti-corruption and ethics guidance for Southern African SOEs.

\section{Definitions}

The questionnaire requests respondents to describe the overall framework for combating corruption in SADC jurisdictions. For the purpose of this exercise, it may be helpful to provide specific definitions of corruption.

97. According to Transparency International's 2011 Bribe Payers Index, companies in these business sectors are fairly likely to pay bribes. These sectors also represent those in which the majority of SOEs from OECD countries operate, according to data compiled by the OECD Working Party on State Ownership and Privatisation Practices. 
There is no one, internationally accepted definition of corruption. Rather, international instruments like the UN Convention against Corruption (UNCAC) ${ }^{98}$, the OECD Convention on Combating Bribery of Foreign Public Officials in International Business Transactions, and the African Union Convention on Preventing and Combating Corruption define specific corrupt acts that must, or should be ed in States Parties' national implementing legislation.

Therefore, questionnaire respondents are requested to refer to the specific corrupt acts, below, when describing their jurisdiction's framework for fighting corruption. The provisions cited are from the UNCAC, which post-dates the African Union Convention on Preventing and Combating Corruption, and to which all SADC governments are Party.

- Active and passive domestic bribery: UNCAC Art. 15

- Active foreign bribery: UNCAC Art. 16.1

- Embezzlement, misappropriation or other diversion of property by a public official: UNCAC Art. 17

- Trading in influence: UNCAC Art. 18

- Abuse of functions: UNCAC Art. 19

- Illicit enrichment: UNCAC Art. 20

- Bribery in the private sector: UNCAC Art. 21

- Embezzlement of property in the private sector: UNCAC Art. 22

\section{Participation}

Network Members are invited to respond to the questions, below, in writing or via phone interviews. Part 1 focuses on the overall framework for combating corruption and promoting business integrity in SADC countries. Part 2 builds on Part 1: It seeks to identify anticorruption and business integrity measures that SADC governments apply specifically to the SOE sector. Part 3 focuses on the internal steps taken by SOEs themselves to adopt and implement measures to combat corruption and to strengthen the integrity of their business operations.

For Parts 1, and 2 which focuses on the legal framework for combating corruption and promoting business integrity, Members may wish to consult with the appropriate ministries or agencies tasked with enforcing anti-corruption measures (i.e., national anti-corruption agencies, ministries of justice, and/or law enforcement agencies). For Part 3, which focuses on specific measures taken by commercial enterprises to promote business integrity, Members may wish to consult with individual SOEs those working in the private sector on this issue (i.e., business associations, chambers of commerce, and/or civil society). Additional materials, where relevant, are welcome. An example of anti-corruption resources that may be useful references for Network Members is included in Annex 1.

98. www.unodc.org/unodc/en/treaties/CAC/index.html 


\section{Questions}

\section{Part 1: General framework for combating corruption and promoting business integrity}

Part I of this questionnaire focuses on the overall framework for combating corruption and promoting business integrity in countries in the Southern Africa Development Community $(S A D C)$. For this part of the questionnaire, Members may wish to consult with the appropriate ministries or agencies tasked with enforcing anti-corruption measures (i.e., national anticorruption agencies, ministries of justice, and/or law enforcement agencies).

1. Please provide an overview of your government's policy for fighting corruption, as well as practices for implementing this policy.

2. Please provide an overview of the legal framework in your jurisdiction for combating corruption. (See corruption definitions above.) Please specify whether this framework includes corporate liability for corruption offences.

3. Please describe other measures (legal, regulatory, or otherwise) in your jurisdiction that require or encourage clean business practices. For example, these measures could include: the application of corporate liability for corruption crimes; prohibition of falsifying books and records for bribery or for hiding bribery; requirements for reporting suspected corrupt acts; the availability of whistle blower protections; public procurement procedures; the provision of anti-corruption ethics and compliance guidelines ${ }^{99}$; or other such measures.

\section{Part 2: Anti-corruption and business integrity measures applying to the SOE sector}

Part 2 of this questionnaire builds on Part 1, but applies specifically to the SOE sector. It seeks to identify anti-corruption and business integrity measures that SADC governments apply specifically to the SOE sector.

1. Is there a perception in your jurisdiction that corruption poses a challenge to the efficient functioning of SOE's in your jurisdiction? If so, what are the specific perceived challenges?

2. Please provide an overview of your government's policy for fighting corruption and promoting business integrity in the SOE sector, as well as practices for implementing this policy.

3. Please provide an overview of the legal framework in your jurisdiction for combating corruption in the SOE sector. Specifically:

- Does the legal framework described in Question 2 apply to SOEs and their employees? Please specify whether an SOE can be held liable as a legal person under this framework. Please also specify whether SOE employees are considered a "public official" under this framework.

- Are there additional, or separate, legally binding anti-corruption provisions in your jurisdiction that apply specifically to SOEs and their employees? Please specify

99. See Annex 1 for examples of anti-corruption ethics and compliance guidelines for business 
whether an SOE can be held liable as a legal person under these provisions. Please also specify whether SOE employees are considered a "public official" under these provisions.

- Do SOEs in your jurisdiction address corruption and business integrity in their corporate bylaws and/or articles of association? If possible, please provide specific references.

4. Please describe how the measures outlined in Question 6 are implemented and enforced in your jurisdiction. Specifically:

- Which agency or agencies is/are responsible for monitoring SOE implementation of these rules (i.e., the SOE line ministry; the SOE coordinating function; law enforcement; regulatory agencies; and/or the state audit function)

- What tools or powers are these agencies provided to effectively monitor implementation of these rules?

- What procedures are in place to follow up on the monitoring of SOEs' implementation of these rules?

5. Please share examples, if any, of corruption cases involving the SOE sector. What challenges did these cases present? What good practices can be shared from this experience?

6. Please describe your government's approach for promoting business integrity in the SOE sector.

\section{Part 3: Implementation of anti-corruption and business integrity measures in the SOE sector}

Part 3 of this questionnaire focuses on the internal steps taken by SOEs themselves to adopt and implement measures to combat corruption and to strengthen the integrity of their business operations.

1. Please describe challenges your jurisdiction faces promoting business integrity in the SOE sector. Please also describe, if possible, good practices for meeting these challenges.

2. Please provide examples of SOEs in your jurisdiction that have developed and implemented an ethics and compliance programme to prevent and detect corrupt behaviour in its business operations.

3. Please note whether SOEs in your jurisdiction are members of local professional associations and/or business organisations. If so, please note whether these associations and/or organisations have developed, or are developing, anticorruption guidance materials for the private sector. 


\section{ANNEX 2. SELECT REFERENCES}

African Development Bank/African Development Fund (2013), Democratic Republic of Congo: 2013-2017 Country Strategy Paper

African Development Bank, Organisation for Economic Co-operation and Development, United Nations Development Programme (2014), African Economic Outlook 2014, May 2014.

African Union (AU) African Peer Review Mechanism (APRM), Republic of Mozambique: APRM Country Review Report No. 11, July 2010.

African Union (AU) African Peer Review Mechanism (APRM), Republic of Mozambique: African Peer Review Mechanism National Forum - Progress Report on the Implementation of the National APRM Programme of Action, 2010-2012, April 2013.

Bertelsmann Stiftung's Transformation Index (BTI) 2014, Democratic Republic of the Congo Country Report

Chalunda, McSyd Hubert, Corporate Crime and the Criminal Liability of Corporate Entities, UNAFEI Resource Material Series No. 76, December 2008

Chinhamo, Obert and Alouis Munyaradzi Chaumba (2012), Progress on Signature and Ratification of Anti-Corruption Instruments by SADC Member States: Who is Lagging Behind among SADC Member States?, Anti-Corruption Trust of Southern Africa and the Non- State Actors Forum of Zimbabwe.

Cohen, Elin, Thomas Selemane and Mariam Umarji (2014), The State's Engagement in Business in Mozambique ,Mozambique Support Programme for Economic and Enterprise Development (SPEED), USAID/Mozambique, August 2014

Eastern and Southern Africa Anti-Money Laundering Group (ESAAMLG) (2008), Mutual Evaluation Report, Anti-Money Laundering and Combating the Financing of Terrorism: Republic of Seychelles, ESAAMLG 2009.

ESAAMLG, Seychelles: National Strategy for Anti-Money Laundering \& Combating the Financing of Terrorism, September 2010.

EITI (2014), Extractive Industries Transparency Initiative Candidature Application Form: Seychelles, June 2014.

EITI (2012), Rapport ITIE-RDC 2010 
FATF and the Eastern and Southern Africa Anti-Money Laundering Group (2009), Mutual Evaluation Report, Anti-Money Laundering and Combating the Financing of Terrorism: South Africa

IMF (2014), Democratic Republic of the Congo: Staff Report for the 2014 Article IV Consultation, 20 May 2014

IMF (2007), Malawi: Report on the Observance of Standards and Codes_ Fiscal Transparency Module-Update.

IMF (2013), Republic of Mozambique: Staff Report for the 2013 Article IV Consultation, Sixth Review under the Policy Support Instrument, Request for a Three-Year Policy Support Instrument, and Cancellation of Current Policy Support Instrument, IMF Country Report No. $13 / 200$

IMF (2014), Republic of Mozambique: Letter of Intent, Memorandum of Economic and Financial Policies, and Technical Memorandum of Understanding, April 23, 2014

Kodi, Muzong (2008), Corruption et gouvernance en RDC durant la Transition (2003-2006), Institute for Security Studies

Kuris, Gabriel, "Managing Corruption Risks: Botswana Builds an Anti-Graft Agency, 1994 2012," Innovations for Successful Societies, Princeton University, 2013

Martini, Maira. Overview of corruption and anti-corruption in Mozambique, U4 Anti-Corruption Resource Center, March 2012

OECD/African Development Bank (2012), Stocktaking of Business Integrity and Anti-Bribery Legislation, Policies and Practices in Twenty African Countries, OECD Publishing.

OECD (2008), Corruption: A Glossary of International Standards in Criminal Law, OECD Publishing.

OECD (2014), The Foreign Bribery Report: An Analysis of the Crime of Bribery of Foreign Public Officials, OECD Publishing

OECD (2010), Global Forum on Transparency and Exchange of Information for Tax Purposes Peer Reviews: Botswana 2010: Phase 1, OECD Publishing.

OECD (2011), Global Forum on Transparency and Exchange of Information for Tax Purposes Peer Review: The Seychelles 2011: Phase 1: Legal and Regulatory Framework, Global Forum on Transparency and Exchange of Information for Tax Purposes: Peer Reviews, OECD Publishing.

OECD (2014), Issues paper on corruption and economic growth, OECD Publishing.

OECD (2014), Southern African Guidelines on the Governance of State-Owned Enterprises, SOE Network for Southern Africa (forthcoming).

OECD (2014), Phase 3 Report on Implementing the OECD Anti-Bribery Convention in South Africa, OECD Publishing. 
OECD (2010), South Africa: Phase 2 - Report on the Application of the Convention on Combating Bribery of Foreign Public Officials in International Business Transactions and the 2009 Recommendation for Further Combating Bribery of Foreign Public Officials in International Business Transactions, OECD Publishing.

Pereira, Pedro Gomes and João Carlos Trindade, Overview and Analysis of the AntiCorruption Legislative Package of Mozambique: Legal Analysis, Basel Institute on Governance, 14 February 2012.

Sultan Balbuena, S. (2014), State-Owned Enterprises in Southern Africa: A Stocktaking of Reforms and Challenges, OECD Corporate Governance Working Papers, No. 13, OECD Publishing.

Hardoon, Deborah and Finn Heinrich (2011), Bribe Payers Index 2011, Transparency International.

United Nations Conference of the States Parties to the UNCAC, Executive Summary of the review of Zimbabwe's Implementation of the UNCAC, CAC/COSP/IRG/1/2/1/Add.17, June 2013

UNODC and the Protection and Ethics Unit of the United Nations Interregional Crime and Justice Research Institute (UNICRI) (2009), Technical guide to the United Nations Convention against Corruption.

UNODC (2013), Country Review Report of South Africa on the Implementation of Chapter II and Chapter IV of the United Nations Convention against Corruption: South Africa.

UNODC (2012), Legislative guide for the implementation of the United Nations Convention against Corruption, second revised edition 2012.

UNODC (2012), UNCAC Review - Botswana Self-Assessment

United States Department of State Bureau of Democracy, Human Rights and Labor (2011), Country Reports on Human Rights Practices for 2011: Democratic Republic of Congo

World Bank (2010), Good-Practice Note: Governance and Anti-Corruption Innovations in the Malawi Social Action Fund Project, No. 131/June 2010.

World Bank (2014), International Bank for Reconstruction and Development Program Document on a Proposed Loan in the Amount of US\$7.0 Million to the Republic of Seychelles for the Third Sustainability and Competitiveness Development Policy Loan, Report No. 83120-SC, August 29, 2014.

Zinyama, Tawanda, "Efficiency and Effectiveness in Public Sector Auditing: An Evaluation of the Comptroller and Auditor General's Performance in Zimbabwe from 1999 to 2012," International Journal of Humanities and Social Science, Vol. 3 No. 7, April 2013. 


\title{
OECD Corporate Governance Working Papers
}

\author{
http://www.oecd.org/daf/ca/oecdcorporategovernanceworkingpapers.htm
}

\begin{tabular}{|c|c|c|}
\hline $\mathrm{N}^{\mathrm{o}} 17$ & 7 Aug 2015 & $\begin{array}{l}\text { How is corporate governance in Japan changing?: Developments in listed } \\
\text { Rompanies and roles of institutional investors } \\
\text { Ryoko Ueda }\end{array}$ \\
\hline $\mathrm{N}^{\mathrm{o}} 16$ & 12 Feb 2015 & $\begin{array}{l}\text { Corporate Bonds, Bondholders and Corporate Governance } \\
\text { Serdar Çelik, Gül Demirtaş and Mats Isaksson }\end{array}$ \\
\hline $\mathrm{N}^{\mathrm{o}} 15$ & 30 Sep 2014 & $\begin{array}{l}\text { Corporate Governance Enforcement in the Middle East and North Africa: } \\
\text { Evidence and Priorities } \\
\text { Alissa Amico }\end{array}$ \\
\hline $\mathrm{N}^{\mathrm{o}} 14$ & 23 Jul 2014 & $\begin{array}{l}\text { State-Invested Enterprises in the Global Marketplace: Implications for a Level } \\
\text { Playing Field } \\
\text { Hans Christiansen, Yunhee Kim }\end{array}$ \\
\hline $\mathrm{N}^{\mathrm{o}} 13$ & 15 Jan 2014 & $\begin{array}{l}\text { State-Owned Enterprise Governance: A Stocktaking of Reforms and Challenges } \\
\text { in Southern Africa } \\
\text { Sara Sultan Balbuena }\end{array}$ \\
\hline $\mathrm{N}^{\mathrm{o}} 12$ & 3 Dec 2013 & $\begin{array}{l}\text { Colombian SOEs: A Review Against the OECD Guidelines on Corporate } \\
\text { Governance of State-Owned Enterprises } \\
\text { Héctor Lehuedé }\end{array}$ \\
\hline $\mathrm{N}^{\mathrm{o}} 11$ & 3 Dec 2013 & $\begin{array}{l}\text { Institutional Investors as Owners: Who are they and what do they do? } \\
\text { Serdar Çelik, Mats Isaksson }\end{array}$ \\
\hline $\mathrm{N}^{\mathrm{o}} 10$ & $11 \mathrm{Jul} 2013$ & $\frac{\text { Making Stock Markets Work to Support Economic Growth }}{\text { David Weild, Edward Kim, Lisa Newport }}$ \\
\hline $\mathrm{N}^{0} 9$ & 11 Jul 2013 & $\begin{array}{l}\text { Disclosure of Beneficial Ownership and Control in Indonesia } \\
\text { Fianna Jurdant }\end{array}$ \\
\hline $\mathrm{N}^{\mathrm{o}} 8$ & 19 Apr 2013 & $\begin{array}{l}\text { Who Cares? Corporate Governance in Today's Equity Markets } \\
\text { Mats Isaksson, Serdar Çelik }\end{array}$ \\
\hline $\mathrm{N}^{\circ} 7$ & 18 Jan 2013 & $\begin{array}{l}\text { Beneficial Ownership and Control: A Comparative Study - Disclosure, } \\
\underline{\text { Information and Enforcement }} \\
\text { Erik P.M. Vermeulen }\end{array}$ \\
\hline $\mathrm{N}^{\circ} 6$ & 18 Jan 2013 & $\begin{array}{l}\text { Balancing Commercial and Non-Commercial Priorities of State-Owned } \\
\text { Enterprises } \\
\text { Hans Christiansen }\end{array}$ \\
\hline $\mathrm{N}^{\circ} 5$ & 1 Aug 2011 & $\begin{array}{l}\text { The Size and Composition of the SOE Sector in OECD Countries } \\
\text { Hans Christiansen }\end{array}$ \\
\hline
\end{tabular}




\begin{tabular}{|c|c|c|}
\hline $\mathrm{N}^{\circ} 4$ & 1 Aug 2011 & $\begin{array}{l}\text { Competitive Neutrality and State-Owned Enterprises in Australia: Review of } \\
\text { Practices and their Relevance for Other Countries } \\
\text { Matthew Rennie, Fiona Lindsay }\end{array}$ \\
\hline $\mathrm{N}^{\circ} 3$ & 1 Aug 2011 & $\begin{array}{l}\text { The Exercise of Shareholder Rights: Country Comparison of Turnout and } \\
\text { Dissent } \\
\text { Paul Hewitt }\end{array}$ \\
\hline $\mathrm{N}^{\circ} 2$ & 1 May 2011 & $\begin{array}{l}\text { Enhancing the Role of the Boards of Directors of State-Owned Enterprises } \\
\text { W. Richard Frederick }\end{array}$ \\
\hline $\mathrm{N}^{\circ} 1$ & 1 May 2011 & $\frac{\text { Competitive Neutrality and State-Owned Enterprises }}{\text { Antonio Capobianco, Hans Christiansen }}$ \\
\hline
\end{tabular}

